\title{
Iowa Physicians: Legitimacy, Institutions, and the Practice of Medicine
}

\author{
Part Two \\ Putting Science into Practice, \\ 1887-1928
}

\section{SUSAN C. LAWRENCE}

IN NOVEMBER 1928, the University of Iowa celebrated the opening of two new buildings on its west-side campus: the University of Iowa Hospital and the Medical Laboratories. Both buildings signified the profound transformation in medical training, medical care, and the medical sciences that had taken place in Iowa over the previous four decades. Both represented a new political and academic confidence that hospitals and laboratories held great promise for the future of medical care and medical knowledge. And both had required an investment of time, money, and faith in science that would have been inconceivable to Iowa taxpayers in the mid-1880s.

Between the passage of Iowa's Medical Practice Act in 1886 and the building celebration in Iowa City in 1928, mainstream medicine's prestige increasingly rested on its association with laboratory sciences and with the devices of a new technological age. The startling efficacy of a few laboratory-discovered treat-

In addition to the thanks I expressed in part one to those who contributed to this history of medicine in Iowa, I wish to gratefully acknowledge the ongoing and deeply appreciated assistance of the staff of the State Historical Society of Iowa Libraries and Special Collections in both Iowa City and Des Moines.

THE ANNALS OF IOWA 62 (Winter 2004). (C) The State Historical Society of Iowa, 2004. 
ments, such as diphtheria anti-toxin (1893), and diagnostic tools, most notably x-rays (1896), made educated physicians' claims that their professional knowledge rested on science more convincing than ever before. ${ }^{1}$ The increasing prestige of sciencebased medicine, much of which came from European universities and research institutes, did not, however, translate easily into increasing professional cohesion or political power for ordinary American doctors. During these decades, physicians in Iowa celebrated the insights that science brought to understanding health and disease, but they also struggled with exactly what those insights meant for their own practices and medical institutions. Iowa's politicians and ordinary citizens appreciated the wonders of medical science and technology, but they still refused to give regular physicians a monopoly over medical practice based on the assertion that alternative systems, such as chiropractic, were unscientific. Iowans were cautious, as well, about paying too much, too soon, for the emerging institutions and applications of scientific medicine.

This article focuses on the implications that the medical sciences and medical research had for Iowa's physicians and citizens in the state between the late 1880s and the late 1920s. It draws on work by historians of American medicine, science, and technology who have sought to understand the complex ways that claims to knowledge and technical expertise intersected with political power and social values in late nineteenthand early twentieth-century America. ${ }^{2}$

1. The best catalogue of discoveries and innovations in the medical sciences is still Leslie T. Morton, A Medical Bibliography (Garrison and Morton): An Annotated Check-List of Texts Illustrating the History of Medicine, 4th ed. (Aldershot, Hampshire, 1983). Charles Singer, A Short History of Medicine (Oxford, 1962), is dated but still useful for the period before 1950 .

2. This rich literature includes Christopher P. Toumey, Conjuring Science: Scientific Symbols and Cultural Meanings in American Life (New Brunswick, NJ, 1996); Charles E. Rosenberg, No Other Gods: On Science and American Social Thought, rev. ed. (Baltimore, 1997); Ronald G. Walters, ed., Scientific Authority and Twentieth-Century America (Baltimore, 1997); John Harley Warner, "The History of Science and the Sciences of Medicine," in Critical Problems in the History of Science, ed. Arnold Thackray, Osiris, 2d ser., 10 (1994); Steven C. Martin, "Chiropractic and the Social Context of Medical Technology, 1895-1925," Technology \& Culture 34 (1993), 809-16; idem, "'The Only Truly Scientific Method of Healing': Chiropractic and American Science, 1895-1990," Isis 85 (1994), 206-27. 
The second in a three-part series offering an overview of the history of medicine in Iowa from Euro-American settlement through World War II, this survey, like part one, concentrates on physicians, medical institutions, public health, and state laws. ${ }^{3}$ Developments in these areas shaped the ways Iowans both received health care and, through legislation, tried to translate medical knowledge and values into public benefits. Such a perspective entails omissions. Physicians were by no means the only people who served the ill and injured between 1887 and 1928. Midwives, nurses, dentists, pharmacists, neighbors, relatives, itinerant healers, and nostrum purveyors all provided a range of help and hope to the sick, and much more needs to be discovered about their relationships to physicians and to ordinary people. Individual patients' firsthand experiences with health care are also largely absent from this survey, as are details about how local city and county governments implemented (or ignored) directives from Des Moines about public health. Understanding the ways that both patients and local authorities perceived changes in medical knowledge and practice provides an important corrective to physician-centered medical history; I hope that this essay stimulates such contributions. Similarly, more work on the political negotiations behind the scenes of legislative and policy decisions will reveal important insights into how lay people interpreted and evaluated proposals to improve the health of Iowans by following the advice of medical experts.

I argued in part one that activist physicians with different therapeutic philosophies worked to establish professional identities in Iowa between 1850 and 1886 by forming medical societies, creating medical schools, establishing public health law and a state board of health, and, finally, securing legislation requiring state licensing of medical practitioners. Such organizations, institutions, and laws provided a basic framework for expanding-and limiting-claims for medical authority based on the status of science in the succeeding decades.

3. For part one, see Susan C. Lawrence, "Iowa Physicians: Legitimacy, Institutions, and the Practice of Medicine," Part One, "Establishing a Professional Identity, 1833-1886," Annals of Iowa 62 (2003), 151-200. 
This essay begins with a discussion of the legislation covering medical practice in Iowa, including the advent of osteopathic and chiropractic practitioners, and demonstrates how the Iowa Board of Medical Examiners used its authority to shape educational standards in the state. The account continues with a look at the ways that the study of bacteriology, the archetypal laboratory science of the late 1880 s to the 1910 s, came to Iowa not only as a subject to be taught in medical school, but also as a set of practices that established physicians had to confront and consider in their own work with patients. Meetings of county medical societies and the annual meeting of the Iowa Medical Society became increasingly important avenues for disseminating information about new discoveries, along with physicians' personal experiences with changes in practice and in the profession.

Hospitals, no longer just for the very poor, started to become vital adjuncts to ordinary medical care, places where the sick and injured could be more efficiently watched, tested, treated, and operated upon. All classes of Iowans and, indeed, all of their physicians, ideally needed access to these institutions and the benefits of the scientific medicine that could be found in ones that were well equipped and well staffed. Thus, the number of hospitals in Iowa increased significantly between 1890 and 1930 (from 21 to 175), supported by Iowans' charitable donations, tax dollars, and direct payments for services.

The laboratory sciences increasingly appeared in public health regulations and procedures, as the state monitored Iowans (and their animals) for bacteriological evidence of infectious diseases. In the early years of the twentieth century, public health observers and social critics found that the data on deaths and diseases compiled by the State Board of Health provided numerical evidence for problems in Iowa, problems already familiar to Americans but now indisputably visible in tables and graphs. Of these, tuberculosis infections, child health, and infant and maternal mortality, so long associated with urban squalor, seemed particularly urgent to address in rural Iowa, as they countered the presumed innate healthiness of farm and smalltown life. As these issues also involved Iowans with federal programs, accounts of them illustrate a growing theme in twentiethcentury health care: the politics of "state medicine" encroaching on private practice. 


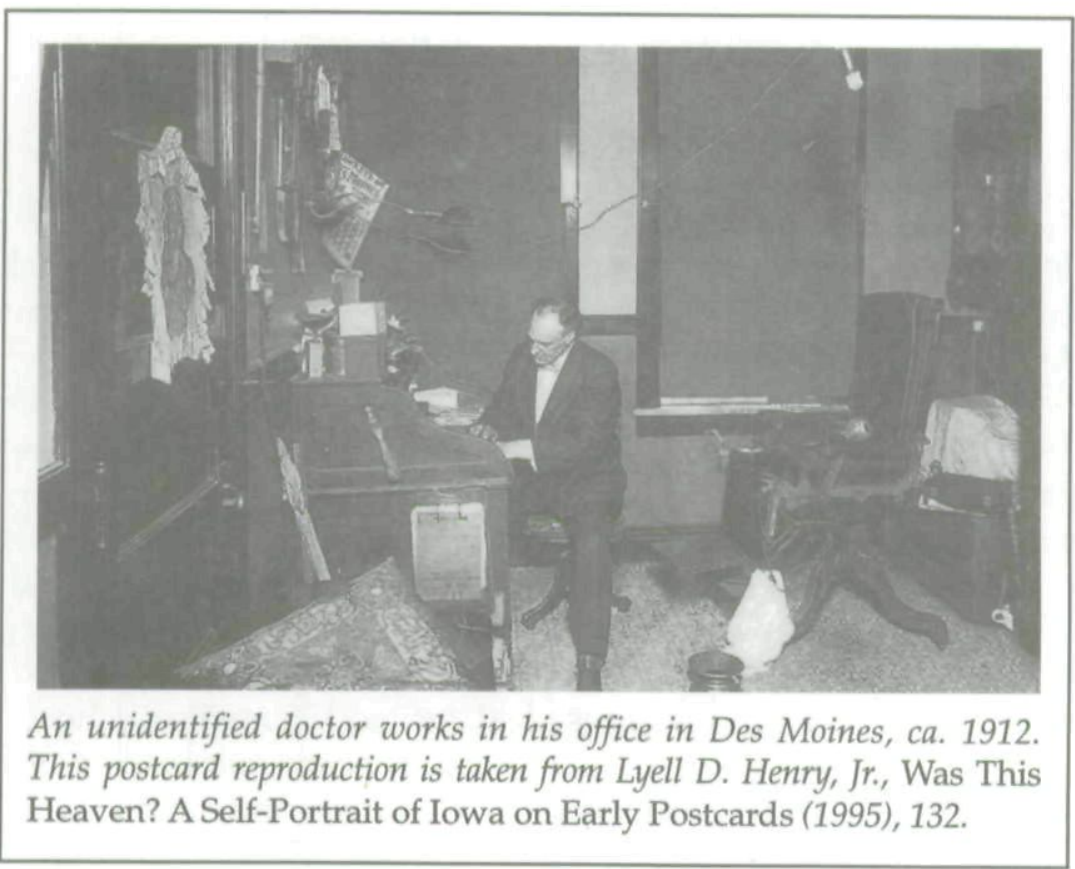

The major conclusion of this article is straightforward. The narrative sets out the chronology of institutional and professional changes in Iowa, along with a survey of major public health concerns and programs. In the end, these all converge to suggest one of the major consequences of the advent of sciencebased medicine in Iowa: Scientific medicine was expensive, and it needed large towns, preferably cities, to flourish. Medical schools, hospitals, and laboratories needed an urban population base. Physicians began to retreat from rural areas and small towns, and, as early as 1896, doctors lamented the passing of the "old-time country family physicians." The general practitioner of the 1880s was hard-working and dedicated and did not expect a large income, but such virtues "availed not against the onward march of science. ${ }^{\prime 4}$ Where the quality of medical practitioners was one of the key political issues of the 1860 s to 1880 s in Iowa, by the early 1920 s the profession reluctantly fore-

4. H. C. Markham, "The Passing of the Old Time 'Family Doctor,'" Iowa Medical Journal (hereafter cited as IMJ) 2 (1896), 386-87. 
saw the political battles of the future: the cost of, and equitable access to, good medical care.

\section{State Licensing, Professional Standards, and Medical Education}

In much of the literature on the history of American medical education, professional standards, and state licensing laws, the founding of The Johns Hopkins University School of Medicine, which opened in 1893, and the Flexner Report, published in 1910, are the key events that transformed the quality of American medical schools and so, ultimately, the quality of American medical practitioners. Johns Hopkins, its admirers believed, embodied the rigorous German model of research-focused higher professional education. Thus it became the institution that all good medical schools tried to emulate. Abraham Flexner, with Johns Hopkins as his ideal, visited 155 medical schools in the United States and Canada and exposed the inadequate facilities and substandard teaching of many proprietary schools and marginal university colleges. Because Flexner's research was funded by the Carnegie Foundation for the Advancement of Teaching, not the American Medical Association or some other group overtly supported by medical interests, lay commentators took his report as a relatively unbiased call for reforms needed to improve medicine for the American people rather than simply to serve a medical elite determined to reduce competition by shutting down perfectly passable, if plain, schools. ${ }^{5}$ Flexner stated nothing that had not already been noted in medical meetings and journals for twenty years or more, but, as historian Kenneth Ludmerer has put it, the publicity given to his report made the reform of medical education "a broad social

5. A. McGehee Harvey et al., A Model of Its Kind (Baltimore, 1989); Thomas Neville Bonner, "The German Model of Training Physicians in the United States, 1870-1914: How Closely Was It Followed?" Bulletin of the History of Medicine 64 (1990), 18-34. As Bonner points out, Americans idealized a distorted view of German medical education. For surveys, see Kenneth M. Ludmerer, Learning to Heal: The Development of American Medical Education (New York, 1985); idem, Time to Heal: American Medical Education from the Turn of the Century to the Era of Managed Care (New York, 1999); William G. Rothstein, American Medical Schools and the Practice of Medicine (New York, 1987); Richard Harrison Shyrock, The Unique Influence of The Johns Hopkins University on American Medicine (Copenhagen, 1954). 
movement similar to other reform movements of progressive era America." The public then supported the "Flexnerian revolution," as dozens of medical schools raised entrance standards and poured money into faculty and facilities to ensure that "the best possible scientific training be made available to every person studying medicine." ${ }^{\prime 6}$

Certainly ideas and institutions at the national level influenced the changes in medical education and professional standards in Iowa between the 1880s and late 1920s. In Iowa, however, the adoption and administration of state licensing laws had an effect that has not received much credit in accounts trying to make sense of developments in Iowa or across the entire country. ${ }^{7}$ All the discussion of higher admission requirements and curricular reform among the physicians who gathered for meetings of the American Medical Association (founded 1847), the Association of American Medical Colleges (1876), or the AMA Council on Medical Education (1904) mattered little without the power of law to regulate medical practice. As Flexner observed in his report, state licensing boards were the "instruments through which the reconstruction of medical education will be largely effected. ${ }^{\prime \prime}{ }^{8}$ Iowa's State Board of Medical Examiners had actually done much of the "reconstruction" before Flexner set foot in the state. At issue after 1910 was whether Iowa could sustain a viable, university-based medical school that could participate in the "Flexnerian revolution," given the state's economic base and distribution of population.

In 1887, when the 1886 Medical Practice Act went into effect, Iowa had five medical schools offering medical training in three different therapeutic philosophies (see table 1). ${ }^{9}$ The College of

\section{Ludmerer, Time to Heal, 5, 6.}

7. Histories of Iowa medicine include Samuel Levey et al., The Rise of a University Teaching Hospital, A Leadership Perspective: The University of Iowa Hospitals and Clinics (Chicago, 1996), 34-35, 59-60. All of the changes to admission requirements and the curriculum described for the University of Iowa College of Medicine were first mandated by the Iowa Board of Medical Examiners.

8. Quoted from Abraham Flexner, Medical Education in the United States and Canada (New York, 1910), in Robert C. Derbyshire, Medical Licensure and Discipline in the United States (Westport, CT, 1969), 8.

9. For details on the diversity of medical philosophies, see Lawrence, "Iowa Physicians," part one, 154-61. 


\section{THE ANNALS OF IOWA}

\section{TABLE 1}

MEDICAL SCHOOLS IN IOWA, 1880-1930

Keokuk

\begin{tabular}{|l|l|l|l|l|l|}
\hline $\begin{array}{l}\text { College of } \\
\text { Physicians and Surgeons }\end{array}$ & proprietary & $1850-1899$ & $\begin{array}{l}\text { merged as } \\
\text { Keokuk Medical } \\
\text { College }\end{array}$ & 1899-1908 & $\begin{array}{l}\text { merged } \\
\text { with Drake } \\
\text { University }\end{array}$ \\
\hline Keokuk Medical College & proprietary & $1890-1899$ & .
\end{tabular}

The University of Iowa, Iowa City

\begin{tabular}{|l|l|l|l|l|l|}
\hline Medical Department & public & $1868-1900$ & $\begin{array}{l}\text { College of } \\
\text { Medicine }\end{array}$ & $1900-$ & $\begin{array}{l}\text { absorbed Drake } \\
\text { students, 1913 }\end{array}$ \\
\hline $\begin{array}{l}\text { Homeopathic } \\
\text { Medical Department }\end{array}$ & public & $1877-1900$ & $\begin{array}{l}\text { Homeopathic } \\
\text { Medical College }\end{array}$ & $1900-1919$ & \\
\hline
\end{tabular}

\section{Des Moines}

\begin{tabular}{|l|l|l|l|l|}
\hline $\begin{array}{l}\text { Iowa Eclectic } \\
\text { Medical College }\end{array}$ & $\begin{array}{l}\text { Medical } \\
\text { Department, } \\
\text { Drake } \\
\text { University }\end{array}$ & $1881-1887$ & proprietary & $1887-1893 ?$ \\
\hline $\begin{array}{l}\text { Iowa College } \\
\text { of Physicians and } \\
\text { Surgeons }\end{array}$ & proprietary & $1882-1887$ & $\begin{array}{l}\text { Medical } \\
\text { Department, } \\
\text { Drake University }\end{array}$ & $\begin{array}{l}\text { 1887-1913 } \\
\text { students absorbed by the } \\
\text { University of lowa }\end{array}$ \\
\hline $\begin{array}{l}\text { King Eclectic } \\
\text { Medical College }\end{array}$ & proprietary & $1883-1889$ & $1898-$ & $\begin{array}{l}\text { (now Des Moines University College of Osteopathic } \\
\text { Medicine) }\end{array}$ \\
\hline $\begin{array}{l}\text { Still College of } \\
\text { Osteopathy }\end{array}$ & proprietary & & \\
\hline
\end{tabular}

\section{Sioux City}

\begin{tabular}{|l|l|l|l|}
\hline $\begin{array}{l}\text { Sioux City } \\
\text { College of Medicine }\end{array}$ & proprietary & $1889-1908$ & merged with the University of South Dakota \\
\hline
\end{tabular}

\section{Council Bluffs}

\begin{tabular}{|l|l|l|l|}
\hline $\begin{array}{l}\text { Council Bluffs } \\
\text { Medical College }\end{array}$ & proprietary & $1893-1895$ & no graduates \\
\hline
\end{tabular}

\section{Davenport}

\begin{tabular}{|l|l|l|l|l|l|}
\hline $\begin{array}{l}\text { Palmer [Chiropractic] } \\
\text { School and Cure }\end{array}$ & proprietary & $1897-1907$ & $\begin{array}{l}\text { Palmer School } \\
\text { of Chiropractic }\end{array}$ & $1907-$ & $\begin{array}{l}\text { (now Palmer } \\
\text { University) }\end{array}$ \\
\hline
\end{tabular}


Physicians and Surgeons in Keokuk, the Medical Department of the University of Iowa in Iowa City, and the Medical Department of Drake University in Des Moines all taught "regular," mainstream medicine. Despite vigorous protests from the regular medical faculty, the state Board of Regents implemented legislation passed in 1876 and started a homeopathic medical program at the University of Iowa. The Homeopathic Medical Department enrolled its first students in 1877; they took several courses (such as anatomy and surgery) with the students in the regular Medical Department but had their own lectures and examinations on homeopathic therapy. ${ }^{10}$ The Iowa Eclectic Medical College opened in Des Moines in 1881 as the Medical Department of Drake University; in 1886 that arrangement ceased, and the Iowa Eclectic Medical College continued as an independent school until about 1893, joined briefly by the King Eclectic College in Des Moines (1883-1887). Following a more open, empiricist philosophy, eclectics favored using any therapeutic regimen that seemed to offer relief to the suffering, even if mainstream physicians had rejected the treatment as clearly not grounded in contemporary scientific principles. Serious disagreements existed among regulars, homeopaths, and eclectics over the empirical and theoretical basis for choosing treatments for diseases; appealing to "science" failed to resolve their disputes.

Representatives from regular, homeopathic, and eclectic medicine nevertheless decided to overlook their differences in order to support legislation creating the State Board of Health in 1880, and again to pass the Medical Practice Act in 1886. As wide as the gulfs among them were on matters of therapeutic philosophy, common interest in regulating medical practice, especially in making it illegal to practice medicine (broadly defined) without a license, allowed a truce. At least the regular, homeopathic, and eclectic physicians involved in getting the

10. Stow Persons, "The Decline of Homeopathy-The University of Iowa, 18761919," Bulletin of the History of Medicine 65 (1991), 75-77; John T. McClintock, "Medical Education in Iowa," in One Hundred Years of Iowa Medicine: Commemorating the Centenary of the Iowa State Medical Society, 1850-1950 (Iowa City, 1950), 296-304. In 1900, when the University of Iowa was reorganized into colleges, it gained two colleges of medicine: the College of Medicine and the Homeopathic Medical College, each of which had its own faculty and curriculum. 
licensing act through the legislature agreed that, starting on January 1,1887 , legitimate medical practitioners in Iowa had to meet minimal standards of medical education, either with a degree from an acceptable medical school or by passing a set of state examinations in "anatomy, physiology, general chemistry, pathology, therapeutics, and the principles and practice of medicine, surgery and obstetrics." ${ }^{11}$ The act gave established doctors with or without a medical degree six months to provide the new Board of Medical Examiners (which was made up of the physician members of the State Board of Health) with evidence of having practiced in the state for at least five years; those who could do so were granted a license without examination. ${ }^{12}$

As with so much regulatory legislation, the effect that the Medical Practice Act had on changing standards for medical education and medical practice in Iowa between the late $1880 \mathrm{~s}$ and late 1920s depended on how the group charged with implementing the law used its authority. The legislature gave the Board of Medical Examiners relatively broad powers in 1886. It was up to the board, for example, to decide if a medical school was in "good standing" and hence whether or not the board would recognize the school's degrees as sufficient for a license

11. 1888 Code of Iowa, Title XII, chap. 8f. When the General Assembly set up a committee in 1897 to consider revisions to the Medical Practice Act, the group included representatives from the Iowa Eclectic Association and the Hahnemann Society (previously the Iowa Homeopathic Society). These practitioners probably had a hand in changing the wording of the act to recognize explicitly that the board had to give separate examinations "in materia medica, therapeutics and the principles and practice of medicine... corresponding to the school of medicine which the applicant desires to practice." 1897 Code of Iowa, Title XII, chap. 17, sec. 2576; Minutes of Meetings, 1/27-29/1897, Board of Medical Examiners, State Department of Health, State Archives of Iowa, State Historical Society of Iowa, Des Moines.

12. The makeup of the Iowa State Board of Medical Examiners changed over the years discussed in this article. From 1886 to 1913, it consisted of the seven physician members of the Board of Health, plus the physician-secretary; from 1913 to 1924, the four physicians and the physician-secretary of the renamed State Board of Health and Medical Examiners formed the board of medical examiners; in 1924, a major reorganization of the Iowa Code led to the formation of a State Department of Health, with a division devoted to all licensing of health-related professions. At that point, the State Board of Medical Examiners was reduced to three physicians. Walter L. Bierring, "The Iowa State Board of Health," in One Hundred Years of Iowa Medicine, 444-46. 
to practice. By 1886, the base line for an acceptable medical education was three years of medical study made up of one year with a preceptor in practice and two years of course work at a medical school. There were no admission requirements for medical schools, and students generally sat through all of the courses given in the four-month academic year twice, submitted a brief thesis, and graduated after an oral examination given by the faculty. Reputable schools needed facilities for anatomical study by human dissection, decent lecture rooms, a library, and the opportunity for clinical instruction at a nearby hospital; otherwise, there were few ready-made standards that state boards could apply to demarcate acceptable from unacceptable schools. ${ }^{13}$

The challenge for the Iowa Board of Medical Examiners, as for similar boards as they appeared in other states, was to set standards with due political and professional savvy. Establishing subject examinations as a backup for applicants without medical degrees or with degrees from unapproved schools tempered the board's power to close medical practice to all but graduates of select medical colleges, and hence to serve what critics viewed as an elitist, monopolizing agenda. Yet, because the physicians on the board wrote the examinations, graded them, and decided on the scores required to pass, they still had considerable influence on the basic content and level of knowledge new practitioners were supposed to demonstrate. No copies of the tests from this period survive, so it is unfortunately impossible to estimate whether the Iowa board set high expectations or low ones. ${ }^{14}$

13. Lawrence, "Iowa Physicians," part one, 173. The Illinois Board of Health was charged with keeping a list of recognized doctors in 1877. It began to survey medical schools to see which were acceptable for degrees and published a series of reports between 1883 and 1889, which the Iowa board likely read and used. Richard Harrison Shyrock, Medical Licensing in America, 1650-1965 (Baltimore, 1965), 53-54.

14. As far as I have been able to determine, no copies of the tests written by the Iowa Board of Medical Examiners have survived for the entire period between 1886 and 1928, nor has any study been done to compare the changing content of any state examinations with the content of medical school courses. The board certainly failed students. In the spring examinations for 1893 , for example, 13 took the tests, but only $5(38 \%)$ passed. Passing required a cumulative average of $80 \%$ in the subject area tests. In 1899 , when all candidates, including those with medical degrees from schools in good standing, had to take the examina- 
Between 1886 and 1910, the Iowa Board of Medical Examiners used its power to determine a medical school's "good standing" to definite effect. Until 1899, the board issued licenses to candidates with degrees from approved schools without further examinations. If a school was not in "good standing," then its graduates had to take the board's examinations, just as if they had no M.D. degree at all, a fact that could hardly attract more tuition-paying students. ${ }^{15}$ Repeated failure to achieve "good standing" very likely contributed to the closing of the King Eclectic College during the 1888-89 school year and the later demise of the Iowa Eclectic Medical College in 1893. Dr. J. D. Miller and Dr. E. H. Carter, both graduates of the Eclectic Medical Institute of Cincinnati, served consecutive terms as medical examiners between 1886 and 1893, and supported the board's decisions. The board licensed graduates of out-of-state eclectic medical schools, moreover, so simply being "eclectic" did not doom these Des Moines colleges. ${ }^{16}$

In 1889 , the board printed and distributed a description of the minimum requirements that it expected for medical colleges to achieve "good standing," including a provision that medical schools had to demand graduation from high school (or the equivalent by examination) for admission. Colleges had to require that students study medicine for three years, including one year with a physician preceptor and two years of attendance at courses (not necessarily in that order), before being ex-

tions, the board, at its second meeting, reconsidered the scores required to pass under the new standards. Twenty-two students took the exams in the summer of 1899: $14(64 \%)$ passed with an $80 \%$ average, while $18(81 \%)$ passed when the required average was lowered to $75 \%$. The board lowered the required average to $75 \%$, but did not, unfortunately, document its reasons. Minutes of Meetings, Board of Examiners, 5/4/1893, 8/1-2/1899. Ludmerer, Time to Heal, 306-7, $403-4 \mathrm{nn}, 474 \mathrm{n}$, encapsulates the ongoing discussion of whether licensing examinations drive changes in medical education or reforms at progressive medical schools drive licensing examinations. See Paul Starr, The Social Transformation of American Medicine (New York, 1982), for a sociological analysis of the relationships between educational standards, economic conditions, and professional closure.

15. 1897 Code of Iowa, Title XII, chap. 17, sec. 2576, 2577.

16. Minutes of Meetings, Board of Medical Examiners, 7/9/1886, 5/11/1887, $5 / 30 / 1888,5 / 7 / 1890,5 / 12 / 1891,11 / 21 / 1891$. The board did recognize the Iowa Eclectic Medical College's good standing for 1887-88. 
amined for the M.D. degree. The same printed description included the board's announcement of new standards that would go into effect for all those who graduated after January 1, 1892. Starting with students entering in 1889, medical schools had to ensure that students followed a structured curriculum, focusing on the science subjects (such as anatomy) before the clinical ones (such as obstetrics), with regular quizzes and examinations, over three years of course work. For graduation, however, students had to have studied medicine for at least four years, so under the new requirements students were still expected to spend a year with a physician preceptor at some point in their medical training. ${ }^{17}$

Despite the early warning, the board's revised expectations for "good standing" apparently caught some of Iowa's medical schools by surprise. Medical graduates from Drake University, Keokuk Medical College, the Keokuk College of Physicians and Surgeons, and the Homeopathic Medical Department of the University of Iowa discovered that their degrees did not entitle them to a license to practice in Iowa without passing the Iowa Board of Medical Examiners' tests. (As Dr. John C. Shrader was, at the time that the curricular changes had to be made, both a member of the Board of Medical Examiners and a professorsoon to be dean-in the Medical Department of the University of Iowa, that school evidently paid attention to the board's notices.) Meetings and correspondence with these medical schools' deans and faculty followed close upon this discovery, and the board felt obliged to make exceptions to its decisions about "good standing" for the Iowa schools that had suffered "a misapprehension" about when the new requirements went into effect. Out-of-state graduates also pleaded with Iowa's board, and a correspondent from the Baltimore Medical College (University of Maryland) even pointed out that the Association of American Medical Colleges, which promulgated the new standards, had recommended that they begin after July (not January) $1,1892 .{ }^{18}$

17. Minutes of Meetings, Board of Medical Examiners, 5/1/1889 (see loose printed sheet from 1889 inserted into the minute book between pages 113 and 114).

18. Minutes of Meetings, Board of Medical Examiners, 5/12/1892, 5/4/1893, $6 / 27 / 1893$. Some of the confusion arose because students, or faculty, or both, 
Representatives from the Iowa board had attended conferences of the State Boards of Health and Examiners and the Association of American Medical Colleges in 1890 and 1891, so presumably the examiners knew that they were ahead of schedule in advancing the national agenda to make medical education more rigorous. Dr. Josiah F. Kennedy, the physician-secretary of the State Board of Health, suffered the consequences as he dealt with the "voluminous correspondence" that ensued. ${ }^{19}$

Until 1894, the board evaluated medical schools based on their printed descriptions and interviews with graduates; if necessary, it summoned faculty to board meetings. Complaints about conditions in the mid-1890s at the Sioux City College of Medicine (opened 1889), the Keokuk Medical College (opened 1889) and the College of Physicians and Surgeons of Keokuk (opened 1850), however, moved the board to send some of its members on inspection visits. In February 1895, for example, the board received reports that the College of Physicians and Surgeons of Keokuk did not come up to minimum standards. The committee it sent to investigate reported back to a special meeting on March 28, detailing the college's unsatisfactory condition. Despite the forceful protest of the college's attorney, John Craig, the board decided that the college was not in "good standing" for its 1894-95 graduates. The college took the censure seriously. A year later it had revised the curriculum, established clear rotation sessions for third- and fourth-year students in the hospital, and renovated the histology and pathology laboratory. The board reinstated the school's "good standing" in May $1896 .{ }^{20}$ State-based on-site inspections and reports thus antedated the more famous evaluations carried out by the AMA's Council on Medical Education, which started in 1907, and those of Abraham Flexner in 1908-09.

As the end of the nineteenth century approached, the Iowa Board of Medical Examiners set forth the next, and arguably the

believed that the new standards applied to those who matriculated after January (or July) of 1892, not to those who graduated.

19. Appointment of delegates, Minutes of Meetings, Board of Medical Examiners, $5 / 7 / 1890,5 / 12 / 1891$.

20. Minutes of Meetings, Board of Medical Examiners, 3/5/1895, 3/28/1895, 5/12-13/1896. 
most significant, step tying state-sanctioned medical practice to institutionalized medical education. In 1896, new state legislation specified that after January 1, 1899, an applicant for licensing both had to have an M.D. degree from an acceptable medical school that provided four full years of course work, including courses in bacteriology and medical jurisprudence, as well as structured clinical instruction, and had to pass the state examinations. Similar requirements were already in place in 22 other states, so Iowans were now following a widespread national movement. ${ }^{21}$ No longer could graduates from inadequate medical colleges still get licensed by passing examinations, nor could those attending even excellent medical schools start practice just by obtaining the M.D. degree. By instituting uniform requirements for medical licensing, the Iowa state board consolidated its authority not only over the independent proprietary medical schools that struggled to meet the ever-increasing costs of laboratory-based teaching, but also over the Medical Department of the University of Iowa, whose graduates complained loudly about being forced to take the state examinations. ${ }^{22}$ The new requirements prompted the Keokuk College of Physicians and Surgeons to merge with the Keokuk Medical College in 1899; joining their resources and tuition income helped them to remain both solvent and in "good standing."

Between the end of 1898 and 1902, the Iowa State Board of Medical Examiners so fully demonstrated its power to prevent a medical school's graduates from practicing legally in the state that the legislature had to intervene. At issue was a new therapeutic philosophy, osteopathy. Andrew Taylor Still, a Missouri

21. Shyrock, Medical Licensing, 55. The board agreed on the plan to increase the standards from three to four years of course work, basically dispensing with credit for time spent with a preceptor, in 1893, when Dr. Kennedy observed that "twenty-one medical colleges in the country are already up to or beyond this standard." The board decided that colleges needed a five-year warning to change their curricula, pushing the compliance date to 1898. Minutes of Meetings, Board of Medical Examiners, 5/4/1893, 6/27/1893. The board had added the requirement for courses in bacteriology and medical jurisprudence in 1895 . Ibid., 8/1-2/1895.

22. 1897 Code of Iowa, Title XII, chap. 17, sec. 2582; "A False Step," Journal of the American Medical Association 33 (1899), 1557; reprinted in JAMA 282 (1999), 2196d. I am grateful to Dr. Richard Caplan for calling this item to my attention. 
practitioner, developed osteopathy out of his experience with the benefits of musculo-skeletal manipulation for treating a wide range of conditions. Patients, and then practitioners, flocked to his school in Kirksville, which opened in 1892, and soon spread the practice throughout the Midwest. ${ }^{23}$ Iowans embraced the new practice enthusiastically enough for the legislature to pass an act in 1898 explicitly recognizing osteopathy as a branch of medicine whose practitioners should be licensed by the Iowa Board of Medical Examiners. The board was to offer a separate examination on "the theory and practice of osteopathy," just as there were distinct examinations for the therapeutic preferences of homeopaths and eclectics; there would be no specialized test, however, "until such time as there may be appointed an osteopathic physician on the state board of health and medical examiners."

Regular physicians discovered that they had seriously underestimated osteopathy's popularity, and they were taken aback when this act passed. ${ }^{25}$ The members of the Board of Medical Examiners seemed equally nonplussed when they began to receive applications from practitioners of osteopathy in the summer of 1898 . Noting that they knew nothing about the schools from which these applicants had graduated, the board deferred action until some of its members had visited the institutions. In December 1898, after receiving reports on the osteopathic schools in Kirksville, Missouri, and Quincy, Illinois, the board drew up a list of minimum requirements that an osteopathic medical college had to meet. The requirements were similar to those for regular, homeopathic, and eclectic colleges, but, because osteopathic physicians were forbidden by statute to prescribe drugs or perform major surgery, the course of study was shorter. ${ }^{26}$

23. Norman Gevitz, The D.O.'s: Osteopathic Medicine in America (Baltimore, 1982), 16-18, 35-36, 43-44.

24. 1898 Laws of Iowa, chap. 29.

25. "D.O. [editorial]," IMJ 2 (1896), 326-27; "Osteopathy in Iowa [editorial]," IMJ 4 (1898), 150-54; J. F. Richardson, "President's Address to the Iowa Union Medical Society," IMJ 6 (1900), 564.

26. Minutes of Meetings, Board of Medical Examiners, 8/4-5/1898, 11/2$4 / 1898,12 / 28 / 1898$. Osteopathic schools had to provide 20 months of study, 
Over the next three years, the Iowa Board of Medical Examiners found no osteopathic medical school able to achieve "good standing," including the new Still College of Osteopathy, which opened in Des Moines in 1898. As the board now refused to allow applicants without a degree from an approved school to take the state examinations, no osteopathic physician received a license to practice in Iowa. ${ }^{27}$ By the end of 1901, those supporting osteopathy had apparently had enough of the board's de facto embargo; they found enough legislative favor to secure passage of a new bill in the General Assembly in the spring of 1902. This act still charged the Iowa Board of Medical Examiners with licensing osteopathic physicians, but it specified that the Iowa Osteopathic Association, not the board, would determine which osteopathic medical schools were in "good standing." The law also mandated that all osteopathic physicians in practice in Iowa before July 4, 1902, were to be issued licenses without examinations as long as they held degrees from colleges approved-retroactively - by the Iowa Osteopathic Association. $^{28}$ At its August meeting in 1902, the board was obliged to issue 284 licenses to the osteopathic practitioners with applications on file, as the Iowa Osteopathic Association declared all of their degrees to be from acceptable schools. ${ }^{29}$ After that, graduates from approved osteopathic medical schools took the same state examinations in anatomy, physiology, chemistry, pathology, and obstetrics as did the graduates of the approved regular, homeopathic, and eclectic medical colleges; there were no state examinations in the theory and practice of osteopathy,

in four terms of 5 months each. Those terms could be placed back-to-back, in contrast to the specification that the courses of study in other medical schools had to have only one academic session each year.

27. Ibid., 5/3-4/1899, 5/15-16/1900, 12/18-19/1900.

28. 1902 Laws of Iowa, chap. 158. In the all-too-brief notes of the Senate's Committee on Public Health for the 29th General Assembly, rewording to SF 273 developed in subcommittee had, according to its chairman, "received the endorsement ... . of representatives of the Still School of Osteopathy." This interjection suggests that osteopaths had useful connections with the legislators seeing the bill through the General Assembly. Senate Minutes, Committee on Public Health, 29th General Assembly (1902), 3/26/1902, Secretary of State Papers, State Archives of Iowa, State Historical Society of Iowa, Des Moines.

29. Minutes of Meetings, Board of Medical Examiners, 8/6-7/1902. 
however, until the legislature created the separate board of Osteopathic Examiners in $1913 .^{30}$

Chiropractic emerged as a therapeutic philosophy at the same time that Andrew Taylor Still developed osteopathy, but it had a quite different history as a medical practice in Iowa. Daniel David Palmer, who spent at least part of his life selling fish in Davenport before turning to magnetic healing, developed his ideas on the healing value of spinal manipulation in 1895. He started teaching chiropractic in Davenport in 1898 at a school that his son, Bartlett Joshua Palmer, soon took over. B. J. Palmer, following his father's work, promoted chiropractic as a healing art that tapped into the body's "innate intelligence" and cured by allowing the body's natural powers to flow. As Steven C. Martin has explained, chiropractic resonated with the populism of the late nineteenth and early twentieth century, especially in the Midwest, not only because it rejected laboratory science and technology, which seemed to threaten traditional ways of life, but because it held that professional medical education had become too elitist and too expensive for ordinary American farmers and workers. Both D. D. and B. J. Palmer emphasized that chiropractic was not the "practice of medicine" as defined in law, and they encouraged its practitioners to go to jail rather than pay fines if sentenced for practicing medicine without a license. ${ }^{31}$ In this respect, chiropractic practitioners allied themselves with other "drugless healers," including advocates of magnetic healing and Christian Science, who argued that they did not practice "medicine" because they did not use drugs, surgery, or any other physically invasive means to relieve human discomforts. ${ }^{32}$

While osteopaths-“drugless healers" who did claim to practice medicine-sought, and obtained, licensing acts in

30. State of Iowa vs. G. H. Heath (125 Iowa 585, 1904); 1913 Supplement to the Code of Iowa, sec. 2583-a.

31. Martin, "Chiropractic and the Social Context of Medical Technology"; idem, "The Only Truly Scientific Method of Healing," 201-27; Walter I. Wardell, "Chiropractors: Evolution to Acceptance," in Other Healers: Unorthodox Medicine in America, ed. Norman Gevitz (Baltimore, 1988), 165. See also Saul F. Rosenthal, A Sociology of Chiropractic (Lewiston, NY, 1986).

32. George E. Crawford, "President's Address," IMJ 17 (1910), 21. 
Iowa, chiropractic practitioners had no legal standing until 1921. Supporters of bills that would have established a separate professional, self-regulating status for chiropractic healers tried session after session to get enabling legislation through the General Assembly, only to have it stalled in one committee or another. ${ }^{33}$ Perhaps dissention among chiropractic healers themselves contributed to this standoff, as licensing required submitting to some form of standardization. How persistent Iowa's county attorneys were in prosecuting chiropractors for practicing medicine without a license awaits research in local court records, but it may be that toleration for chiropractic healers also reduced the pressure for legislation. ${ }^{34}$ In 1921 the General Assembly finally passed a bill that set up an independent state licensing board for chiropractic, even though a subcommittee asked to look at a House version of the bill had reported "that there had been so many conflicting arguments presented to the Committee both pro \& con that they were at sea as to what should be done. ${ }^{\prime \prime 35}$ The editor of the Journal of the Iowa State Medical Society then blamed the law on passing political conditions: "the people of the state are not fairly represented by our last legislature," the editorial claimed. "It was only an incident in a strange and unaccountable and insane election." Lay people, it was clear, still refused to accept regu-

33. This conclusion is based on a survey of the Journal of the Senate and the Journal of the House of Representatives for the Iowa General Assembly between 1898 and 1924 . The house journals occasionally (e.g., 1919) referred to petitions about chiropractic from various Iowa towns. Unfortunately, none of these petitions appears to have survived for deposit in the State Archives of Iowa. I am grateful to Sharon Avery and Beth Brannen for their patience in looking.

34. Wardell, "Chiropractors: Evolution to Acceptance," 159-62, 166. There are relatively few references in the Iowa Medical Journal or the Journal of the Iowa State Medical Society to combating chiropractic. But see, for example, "Senator J. H. Allen Resigns," JISMS 6 (1916), 125-26; and "Chiropractors," JISMS 9 (1919), 243. The minutes of the meetings of the Iowa State Board of Medical Examiners are also silent about chiropractic practitioners. As its jurisdiction only extended over licensing physicians, the board could revoke licenses from practitioners who were incompetent, felonious, etc., but it could only direct county attorneys to prosecute individuals it was informed were practicing medicine without licenses.

35. Minutes, Committee on Public Health, House of Representatives, 39th General Assembly, 2/16/1921, Legislative Papers, State Archives of Iowa, Des Moines; 1921 Laws of Iowa, chap. 10; 1924 Code of Iowa, Title VIII, chap. 19. 
lar medicine's claim that chiropractics, along with other drugless healers, were "charlatans." ${ }^{136}$

Relieved of the duty to assess osteopathic medical colleges in 1902, the Iowa Board of Medical Examiners continued its responsibility to evaluate the quality of regular, homeopathic, and eclectic schools whose graduates applied to practice in Iowa. In the first years of the new century, the board seriously took up the question of reciprocity among state licensing boards. As more states required both acceptable degrees and examinations for licensing, it became more challenging for older physicians to move between states. Iowa's board refused to issue a license to practice based on a license from another jurisdiction until enabling legislation was passed in 1904. Having joined the new Confederation of State Examining and Licensing Boards in 1903, however, Iowa's board was ready to start reciprocity agreements with Illinois, Nebraska, and Wisconsin in the spring of 1904 and, by July, with seven other states and the District of Columbia. ${ }^{37}$ From the start, reciprocity arrangements depended on the state boards' mutual assurance that they shared the same requirements for medical education and examinations. Such agreements thus contributed a bureaucratic mechanism for the explicit validation of professional standards across state lines, albeit a voluntary, clumsy, and time-consuming one, as each state board had to approve an individual contract with each state board seeking reciprocity.

As the Iowa Board of Medical Examiners had already learned, setting standards on paper did not necessarily mean that a medical school met them in its facilities and faculty. Early in 1907, the AMA's Council on Medical Education announced that it would begin to inspect and "grade" medical schools.

36. [untitled editorial, 9/15/1921], JISMS 11 (1921), 359; "Chiropractors' Bill," ibid., 180.

37. Shyrock, Medical Licensing, 58-59, 61-62; Minutes of Meetings, Board of Medical Examiners, 11/3/1893, 2/5-6/1895, 12/28/1898, 2/18-19/1903, 5/20-21/1903, 2/17-18/1904, 5/18-19/1904, 7/20-21/1904. The board's minutes for 1904 to 1930 are filled with clues to changing reciprocity agreements that were managed by correspondence and contracts that have not survived, or have not been deposited in the State Archives. See, for example, 1/18/1916, $11 / 23 / 1916,10 / 27 / 1924$, and 5/11/1926.

38. Shyrock, Medical Licensing, 61-62. 
The council issued its first report later that year. It is probably not a coincidence that in the summer of 1907 Iowa's board decided to start its own annual inspection of all of Iowa's medical schools. In the summer of 1908, the subcommittee assigned to visit Iowa's colleges reported frankly to the board on the results of its second annual inspection. The College of Medicine in Iowa City, with approximately 200 students, had excellent laboratories and faculty, but "the clinical advantages, especially in obstetrics and acute cases of disease, are not in keeping with the laboratory facilities. This is an objection which the school cannot overcome because of being located in a small town." The Medical Department of Drake University, although a much smaller school (62 students), had "excellent clinics" and was, overall, "very satisfactory." The Sioux City school (26 students) was basically in "poor condition," as unsatisfactory as it had been in 1907, and could not be considered in "good standing." Finally, the Keokuk Medical College (122 students) had tried hard, but "this Medical College is working against great odds and has a poor outlook for the future. It would not seem advisable for such a school to continue the struggle for existence, and wear out the lives of its professors in a vain effort to compete with institutions having so much more money at their disposal than the Keokuk school can ever hope to have. ${ }^{\prime 39}$

The colleges received copies of the board's evaluation of their institutions. By January 1909, there were only two regular medical schools left in the state, one in Iowa City and one in Des Moines. The Sioux City school had merged with the University of South Dakota, and the Keokuk Medical College had merged with the Medical Department of Drake University, transferring its remaining students to the capital city. ${ }^{40}$ Both had apparently realized, willingly or not, that they could no longer

39. Minutes of Meetings, Board of Medical Examiners, 7/14/1908. The board criticized the homeopathic department of the University of Iowa College of Medicine for the poor condition of the facilities for nurses in its hospital. For the detailed requirements for medical teaching, see the printed pamphlet dated 7/18-19/1908, bound into the minutes. The pamphlet specifies the facilities and equipment required for each preclinical course in the curriculum.

40. Minutes of Meetings, Board of Medical Examiners, 1/21-22/1909. 
survive as independent schools without confidence that their graduates could be licensed to practice medicine.

By the spring of 1909, when Abraham Flexner visited Iowa, the Iowa Board of Medical Examiners had clearly done much to make medical education and licensing in the state more rigorous. Its members knew that none of Iowa's remaining medical colleges approached the quality (and expense) of the best American medical schools, but Iowa's schools were in line with decent colleges in other states. From a state-level perspective, then, medical education was in good shape. From a national perspective, however, especially the perspective of a reformist advocate of regular medicine using the Johns Hopkins University School of Medicine as a model, Iowa's regular medical schools were, at best, acceptable, but unlikely to achieve excellence. Abraham Flexner, a schoolteacher with a Ph.D. in classics from Johns Hopkins, also had little toleration for homeopathy and osteopathy, no matter what ordinary citizens preferred and licensing boards accepted. For him, the University of Iowa's Homeopathic Medical College and the Still College of Osteopathy had no future at all. ${ }^{41}$

The Carnegie Foundation published Flexner's report in 1910. Faced with Flexner's criticisms of their teaching, clinical resources, and laboratories, the discouraged faculty of the Medical Department of Drake University decided to give up. ${ }^{42}$ The citizens of Des Moines and supporters of Drake University had other ideas, however, and rallied to raise money for new teaching laboratories and to start an endowment. By early 1913, the Drake trustees reluctantly realized that maintaining the medical school would still cost too much, and they announced that it

41. Stow Persons, "The Flexner Investigation of the University of Iowa Medical School," Annals of Iowa 48 (1986), 274; Flexner, Medical Education, 222-23. The Homeopathic Medical College closed in 1919 because so few students enrolled. Both homeopathic and eclectic medical schools had disappeared nationally by 1925 . The last explicit mention of an examination for eclectic therapy and practice by the Iowa Board of Medical Examiners appeared in January 1917; the last mention of a homeopathic examination came in July 1921. Minutes of Meetings, Board of Medical Examiners, 1/3/1917, 7/18/1921.

42. Flexner, Medical Education, 222; Minutes of Meetings, Board of Medical Examiners, 4/13/1910; Persons, "Flexner Investigation," 284-85. 
would merge with the University of Iowa's College of Medicine. ${ }^{43}$ Drake's students transferred to Iowa City in the fall of 1913, and a few of the faculty, most notably Arthur Steindler, then a young orthopedic surgeon, went with them.

The University of Iowa's response to Flexner's assessment was much more complicated. Flexner provided the University of Iowa with a preliminary report after his visit in April 1909, and made a second visit, with a second report, in the fall. He strongly recommended that the university face the reality of Iowa's limited resources in both money and population and give up trying to be a full, four-year medical school. The university could probably manage to offer a solid two-year preclinical track, but it would then have to send its students to medical colleges in major urban centers for their clinical years. His published comments were "muted" compared with his first views, because university president George MacLean and William R. Boyd, head of the Finance Committee of the new (1909) State Board of Education, convinced him that the university was deeply committed to improving its College of Medicine. ${ }^{44}$ As historians Stow Persons and Lee Anderson have already detailed, Boyd committed himself to a rough road. To make the University of Iowa's College of Medicine, located in a small town and part of a midwestern, publicly funded university, into a respectable country cousin of the private, massively endowed Johns Hopkins University School of Medicine in urban Baltimore demanded years of effort and hundreds of thousands of dollars between 1913 and $1928 .^{45}$

43. "Improvements to Medical Schools," IMJ 17 (1910), 200; "Drake University College of Medicine," IMJ 16 (1910), 585; "Medical Progress at Drake," IMJ 17 (1911), 457; "Drake Medical School," IMJ 19 (1912-13), 102-4, 410.

44. Persons, "Flexner Investigation," 282; Flexner, Medical Education, 223. For the texts of Flexner's reports sent directly to the University of Iowa, see Appendix D in Levey et al., Rise of a University Teaching Hospital, 444-49, and Levey's discussion, 50-53. See also "Changes in the Faculty of the State University," JISMS 3 (1914), 388-89.

45. Persons, "The Flexner Investigation," 274-91; Lee Anderson, "'A Great Victory': Abraham Flexner and the New Medical Campus at the University of Iowa," Annals of Iowa 51 (1992), 231-51; idem, Internal Medicine and the Structures of Modern Medical Science: The University of Iowa, 1870-1990 (Ames, 1996), 29-55; Levey et al., Rise of a University Teaching Hospital, 52-62; John Bowman, "The Future of the College of Medicine," JISMS 2 (1913), 797. 
Early on, some of the reform-resistant, Iowa-bred faculty had to go, to be replaced by highly educated physicians from out of state. The existing hospital administration had to be reorganized and plans drawn up to expand the medical campus. One of the most critical problems, already noted by the Iowa Board of Medical Examiners and then stressed by Flexner, was the challenge of getting enough patients into the 90-bed University Hospital for students to study during their clinical rotations and for faculty to observe as they developed specialty skills and research areas. The population of Iowa City and surrounding counties simply could not provide enough sick and injured people to support a significant medical school. A legislative solution emerged from the growing problem of providing advanced medical care to the state's poor. County governments were responsible for supporting their indigent with food, shelter, clothing, and, when necessary, medical attention. Serious illnesses or injuries often required resources, such as hospital care and specialist treatment, that county supervisors were loath to pay for. In 1915 legislators proposed that the state government pay for the medical needs of indigent children as long as those children went to the University of Iowa Hospital for treatment. That act, better known as the Perkins Law, was followed in 1919 by the Haskell-Klaus Law, which funded medical care for indigent adults sent to the University Hospital. The legislature also allocated tax funds to build several new wings to the 1898 hospital and to construct two new hospitals, the Children's Hospital and the Psychopathic Hospital, both of which opened in 1919 on the west side of the Iowa River. By 1920, the University of Iowa's Hospitals and College of Medicine had a much more distinguished faculty, a much larger patient population, and a much bigger operating income from state revenues than it did in 1910-but it was still no University of Michigan or Johns Hopkins. ${ }^{46}$

The next crucial step required a far larger investment if the University of Iowa's College of Medicine were to have a chance to make a mark at the national level. It was obvious from at least 1919 that the university needed a new, modern general hos-

46. Levey et al., Rise of a University Teaching Hospital, chap. 2. 


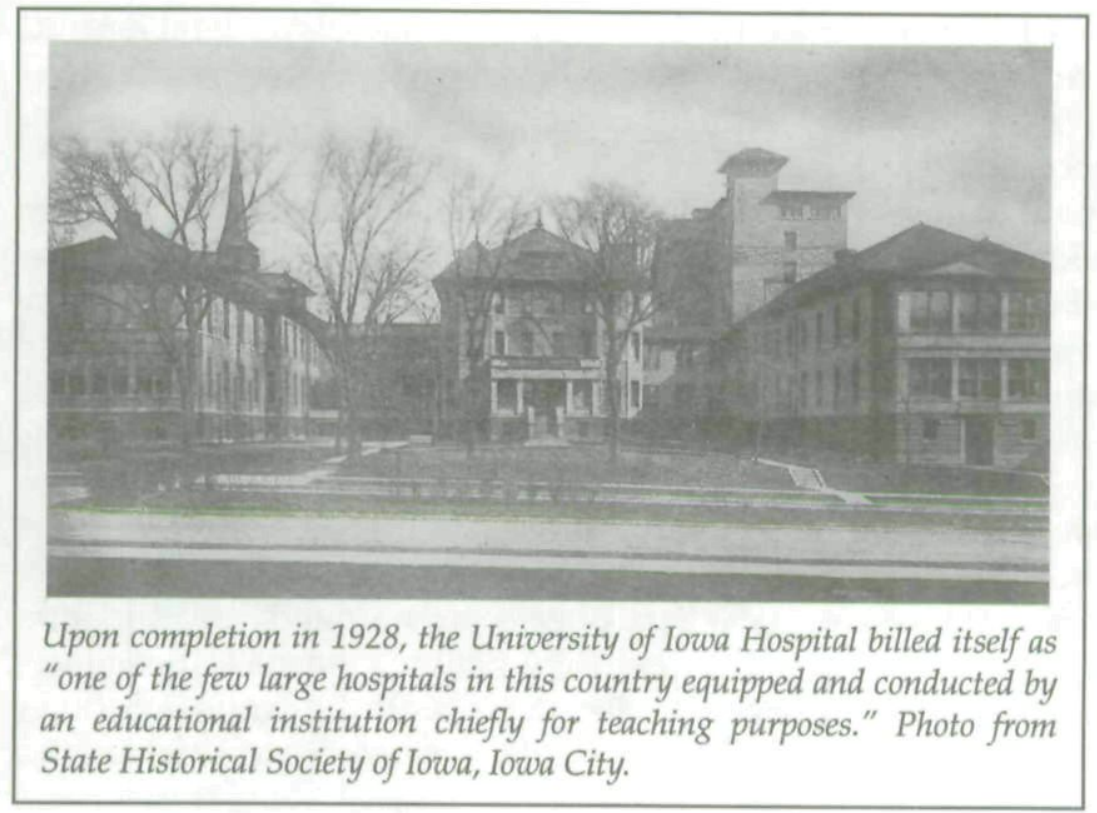

pital and a major building for teaching and research laboratories. A turning point in Iowa's long-term fortunes came in 1920-1922. By that time, Abraham Flexner had become a trustee of the General Education Board (GEB), a foundation established by John D. Rockefeller to promote education in the United States. William Boyd, in meetings with Flexner, outlined the university's plans to revamp its medical school. Flexner had already started to consider the idea that the GEB might support public schools as well as private ones, such as Columbia and Johns Hopkins. Revising his earlier opinions of the University of Iowa's College of Medicine, he took up the vision of transforming it into a model for midwestern progress. After many complex negotiations, in December 1922 the Rockefeller Foundation and the GEB promised to commit $\$ 2,250,000$ towards the new medical campusif the state of Iowa would match it. Despite outright opposition from those who felt that enough tax dollars were already going to the University of Iowa and lukewarm enthusiasm from Iowa physicians who disliked the elitism of some of the university's faculty, the necessary allocation ( $\$ 450,000$ per year for five years) passed the General Assembly in the spring of 1923. The resulting 
$\$ 4.5$ million funded the construction of the new general hospital and the medical laboratories building that were, in matching "red brick with collegiate gothic trim," impressive monuments to university-centered medical education and research. ${ }^{47}$

The higher standards that transformed medical education in Iowa between 1886 and 1928 clearly came with higher costs. As the basis for medical knowledge and care changed under the impact of the laboratory sciences and diagnostic technologies, it became increasingly expensive to create medical practitioners. As both entry qualifications and the number of years of study for medical school took longer to fulfill, more resources were needed to become a doctor. In the 1890 s, a high school diploma (or the equivalent) sufficed for admission to a three-year program to obtain a medical degree, license, and practice; after January 1, 1911, when the Iowa Board of Medical Examiners mandated two years of college-level work for admission to acceptable four-year medical schools, it took at least six years after high school to become a doctor. An editorial in the Iowa Medical Journal noted this trend in 1910 with disquiet. "We appreciate what all this education means to the people but we cannot help but feel that such requirements are going to result in the prohibition of many bright and intelligent young men from entering the study of medicine..$^{\prime 48}$ By the early 1920 s, concerns about the implications of education-intensive medicine had grown, not only because fewer people could afford medical school, but also because fewer physicians settled in rural areas. "The young medical graduate with his scientific training," an editorialist observed in the Journal of the Iowa State Medical Society in 1921, "cannot be attracted to a location where he will have no opportunity to use much of the knowledge he has so painfully and expensively acquired. ${ }^{\prime \prime 9}$

47. Stow Persons, The University of Iowa in the Twentieth Century: An Institutional History (Iowa City, 1990), 79; Anderson, "'A Great Victory,'" 235-51; "Gift to the Iowa State University," JISMS 13 (1923), 61-62; "Iowa State University Receives the $\$ 450,000$ Appropriation," JISMS 13 (1923), 208.

48. Minutes of Meetings, Board of Medical Examiners, 7/22/1910. The AMA Council on Medical Education supported this new standard in 1910. "The Failure of Medical Schools," IMJ 16 (1910), 534-35.

49. "Medical Coordination and Cooperation," JISMS 11 (1921), 262; "Problems in Medical Education and Practice," JISMS 17 (1927), 416-17. 
The Promise of the Laboratory:

\section{Science, Technology, and the Practice of Medicine}

The "Flexnerian revolution" is the term generally used to describe the transformation of medical education after the publication of the Flexner Report, in which Flexner exposed what he considered to be poor, marginal, and mediocre medical schools to public scrutiny. In a larger sense, however, the "Flexnerian revolution" appropriately refers to the widespread adoption and standardization of Flexner's guiding ideology, as embodied in Johns Hopkins University and in the work of his brother, Simon Flexner, a noted pathologist, bacteriologist, and first director of the Rockefeller Institute for Medical Research (1903). Medical knowledge and practice had to be based on science, specifically the science of the research laboratory and the carefully monitored bedsides of the sick. That ideology had been articulated decades before the Flexners came on the scene, of course, but it did not have a significant impact on commonplace medical education and ordinary doctors until the emergence of bacteriology.

For many in Iowa, the awareness that science was rapidly producing new knowledge, and hence new ways to perform old tasks, likely arrived with new gadgets, such as the telephone, and new experts, especially the agricultural chemists, botanists, and entomologists associated with the Iowa Agricultural College and Experiment Station in Ames in the 1880s and 1890 s. For others, that moment may have arrived when a physician, armed with a swab, demanded a throat culture from a sick child, with the peculiar news that it would be sent away to a laboratory to confirm a diagnosis of diphtheria, and prepared a syringe to inject a substance derived from the blood of horses. Bacteriology, more than any other biomedical research of the late nineteenth century, brought a new kind of science into the homes of Iowans, although hearing about mysterious germs and getting strange injections hardly translated into public support for the laboratory or for science in general.

Although the popular media picked up stories about germs, epidemics, and exciting laboratory discoveries, the day-to-day task of spreading the word of the new science fell to individual physicians and to the Iowa State Board of Health. The Board of 
Health had sought to educate Iowans about proper sanitation, individual hygiene, and isolation of the sick since its inception in 1880. In many ways, the discovery of disease-causing germs simply intensified the familiar emphasis on cleanliness and quarantine when dealing with infectious diseases. For much of the 1880 s, established Iowa physicians learned about bacteriology from the medical literature and from attending meetings of the Iowa Medical Society, and quite a few remained skeptical. ${ }^{50}$

University of Iowa botanist Thomas Macbride gave the first courses in Iowa that discussed bacteria-along with fungi, molds, and yeasts-and was likely the first Iowan to culture such microorganisms in his laboratory sometime between 1874 and 1889. Not until Lawrence Littig arrived in 1889, however, did the university have a faculty member trained in the bacteriology of human diseases. According to Walter Bierring's account, Littig showed students "the tubercle bacillus in sputum, anthrax bacilli with spores, and typhoid bacilli with flagella in the microscopic field. ${ }^{\prime \prime 1}$ Bierring was one of Littig's students, and Littig groomed him for a future position at Iowa by helping to send him to Europe for postgraduate study in 1892, immediately after his graduation from the university's Medical Department. Bierring took bacteriology at the University of Heidelberg, worked under Max von Grüber in Vienna, and briefly visited Paris, where he joined Littig, who had just finished studying bacteriology at the Pasteur Institute. Thus equipped, Littig and Bierring returned to Iowa to set up proper courses in microscopic pathology and bacteriology, with all the difficulties of putting into practice what they had learned about tissue preparation and setting up cultures.

50. Terra Ziporyn, Disease in the Popular American Press: The Case of Diphtheria, Typhoid Fever and Syphilis, 1870-1920 (Westport, CT, 1988); Nancy Tomes, The Gospel of Germs: Men, Women, and the Microbe in American Life (Cambridge, MA, 1998); George F. Jenkins, "Contagiousness, Treatment, and Prophylaxis of Scarlatina," Transactions of the Iowa State Medical Society 6 (1883-1885), 130-40; Enos Mitchell, Letter to the editor, IMJ 5 (1899), 143-46.

51. Walter L. Bierring, "The Story of Bacteriology at the University of Iowa," JISMS 27 (1937), 555.

52. For the notes concerning bacteriology and pathology that Bierring kept from lectures during his time in Vienna and Paris, see Dr. Walter Bierring Papers, boxes 1-3, State Archives of Iowa, Des Moines. 


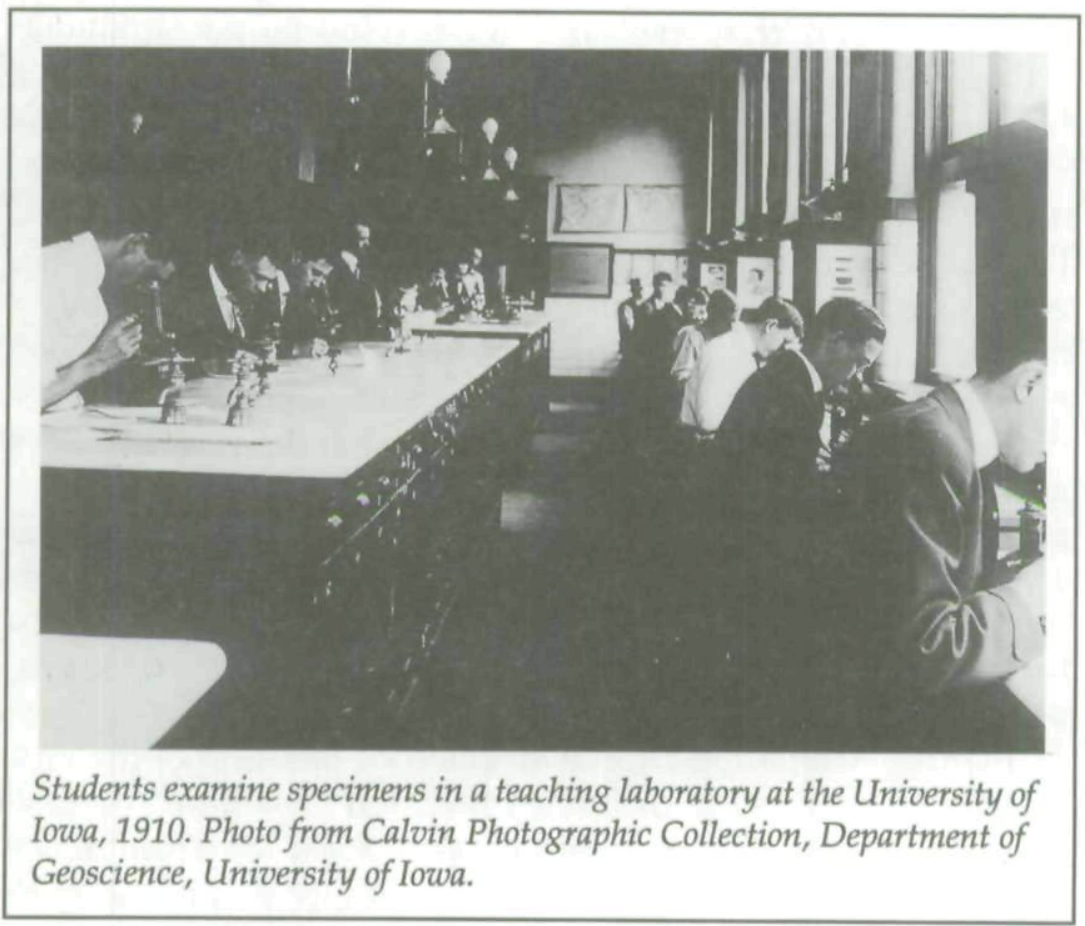

By the spring of 1894 at the latest, physicians outside of medical schools in Iowa were doing some practical bacteriology on their own. In a paper delivered at the Iowa Medical Society's annual meeting in that year, for example, A. L. Wright of Carroll, in his discussion of tuberculosis of the kidney, referred to the importance of diagnosing tuberculosis by identifying the bacillus. ${ }^{53}$ As relatively elementary laboratory equipment and only a few specialized reagents were required for some of the very basic bacteriological and histological work at that time, the ability to perform such diagnostic tests may have spread fairly rapidly among those with microscopes. How reliable those observations were, and how meaningful to patients, are much more difficult to assess, however.

Although Pasteur had had success with his rabies inoculations for treating hydrophobia and with anthrax vaccines to protect sheep from that disease, little in the way of treatments had

53. A. L. Wright, "Surgical Tuberculosis of the Kidney," Transactions of the Iowa State Medical Society 12 (1894), 95-100. 
emerged from bacteriology until the preparation of diphtheria antitoxin. In the summer of 1894, Bierring returned to Paris for the ten-week intensive summer course in bacteriology at the Pasteur Institute. Near the end of the summer, he watched Emil Roux take the students step-by-step through the process of making diphtheria antitoxin by injecting horses with diphtheria toxin, recovering the serum, and using it on patients at the institute's hospital. ${ }^{54}$ The success of the antitoxin treatment was announced to the world at the International Conference of Hygiene and Demography in Budapest that fall, and it became a major news item in the popular press. Bierring's return to Iowa thus brought more than his sound preparation to teach medical students. At the same time that Hermann Biggs, T. Mitchell Prudden, and William Park were orchestrating a newspaper campaign to fund the production of antitoxin by the New York City Board of Health, Bierring was making antitoxin in Iowa. ${ }^{55}$

Bierring, using three horses donated by the dean of the university's Medical Department, had prepared the antitoxin serum by April 1895 . He demonstrated his work at the May meeting of the Iowa Medical Society, where some enthusiasts pressed (unsuccessfully) for a resolution to request the Board of Education to fund the production of antitoxin at the university and to distribute it free to physicians. Bierring did produce about 300 doses, which were used to treat diphtheria that year, but otherwise physicians at that time who wanted to use the antitoxin had to wait to purchase it from commercial sources. ${ }^{56}$ Physicians did use the antitoxin, usually with excellent results, but suspicions about the "horse juice" remained among both doctors and lay people well into the $1920 \mathrm{~s}^{57}$

54. Bierring, "Bacteriology," 555-57, 602-6, 656-59.

55. Evelynn Maxine Hammonds, Childhood's Deadly Scourge: The Campaign to Control Diphtheria in New York City, 1880-1930 (Baltimore, 1999).

56. Transactions of the Iowa Medical Society 13 (1895), 5, 54-72, 606. In 1910 the State Board of Health purchased diphtheria antitoxin at a reduced rate for resale to physicians at antitoxin stations around the state. Guilford H. Sumner, "A Short History of the State Board of Health," JISMS 4 (1914), 478.

57. "Medical news," IMI 2 (1896); M. E. Silver, "The Antitoxin Treatment of Diphtheria," IMJ 8 (1902), 148-50. Hammond, Childhood's Deadly Scourge, discusses the continued resistance to antitoxin, some of which, given contaminated serum and other production problems and frauds, was quite justified. 
Diphtheria was a frightening childhood disease; mortality could be as high as 60 percent during an epidemic of a particularly virulent form. The antitoxin was by no means an infallible cure, as it needed to be given early and in large enough doses to be effective. Before the creation of the antitoxin, the Iowa State Board of Health had tried to manage the disease with notification and quarantine, as diphtheria spread rapidly in schoolrooms and was taken home to infect preschool children, who were the most susceptible. After 1895, the antitoxin lowered the mortality rate among those who received it, but the disease continued to take its toll in regular epidemics. Bacteriologists soon confirmed what a few physicians had already suspected: mild cases were often undiagnosed, convalescents could carry the bacillus for weeks or months after recovery, and there could even be completely asymptomatic carriers. ${ }^{58}$ Public health measures became even more vital as the complexities of the disease undermined the initial expectations that available cure meant easy eradication. ${ }^{59}$

When antitoxin worked, nevertheless, it could do so spectacularly. By demonstrating practical results, bacteriology became the darling of the new sciences. In 1895 the Iowa State Board of Medical Examiners added bacteriology to the list of required subjects to be taught in medical schools. ${ }^{60}$ Bierring found that the summer course he gave on bacteriology each year at the University of Iowa between 1895 and 1901 always filled up quickly with senior medical students and practicing physicians. ${ }^{6}$

The growing number of Iowa physicians who understood how useful bacteriology could be in individual practice and in public health quickly found that their knowledge outstripped the laboratory resources they had access to in ordinary practice. By early 1904 , the medical community had rallied support for a "Bacteriological Laboratory Bill" in the Iowa legislature. As initially proposed, the laboratory would have been in Des Moines,

58. Henry Albert, "Diphtheria Carriers and Medical Inspection of Schools," IMJ 18 (1911), 261-65.

59. J. E. Luckey, "The Physician's Relation to Public Health with a Report on a Diphtheria Epidemic," JISMS 4 (1914), 413-17.

60. Minutes of Meetings, Board of Medical Examiners, 8/1-2/1895.

61. Bierring, "Bacteriology," 656. 
with a generous appropriation. But, as the editor of the Iowa Medical Journal lamented, "for some reason it became a political bobbin, which was kicked from house to senate and from committee to committee and finally was so disfigured that it ended in being an additional appropriation to the laboratory of the State University." ${ }^{\prime 2}$

The State Board of Health Bacteriological Laboratory thus came to the University of Iowa. Its new director, Henry Albert, was a professor in the Department of Pathology with Bierring. In a circular sent to all physicians in the state, Albert explained that the laboratory would perform "routine diagnostic work in connection with diphtheria, typhoid fever, tuberculosis and rabies ... in the interests of the public health." Given the modest budget for the laboratory $(\$ 6,000$ per year, most of which went to salaries), however, it could not do any analysis of public water supplies unless they were implicated in an outbreak of a major disease. Kits for providing cultures for diphtheria, tuberculosis, and typhoid were to be distributed to a "culture station," usually a drugstore, in "every city and town in the state." The state would pay for the diagnostic examination, but the physician had to cover the cost of postage and, if requested, a telephone call to inform the doctor of test results. ${ }^{63}$

Albert knew from the start that having only one state laboratory, and that one in a small city in eastern Iowa, would not be effective for rapid recognition of potential epidemics. The State Board of Health allowed auxiliary laboratories to be established, as long as they met certain standards and their bacteriologists passed an examination given in Iowa City. Over the next decades, a number of hospital laboratories qualified as auxiliaries of the state laboratory, with their directors holding the power to establish and lift quarantines on the basis of diagnostic tests. ${ }^{64}$

62. "The Bacteriological Laboratory Bill," IMJ 10 (1904), 162.

63. Henry Albert, "The State Board of Health Bacteriological Laboratory," IMJ 10 (1904), 436-90. For a list of the 677 culture stations available in 1906, see Henry Albert, "First Annual Report of the Iowa State Board of Health Bacteriological Laboratory," in Thirteenth Report of the Board of Health (Des Moines, 1906), 166-75.

64. See, for example, notices of the auxiliary laboratories at Park Hospital in Mason City and Finley Hospital in Dubuque in JISMS 3 (1913), 27 and JISMS 10 (1920), 37. Dr. Cora Hesselberg was the bacteriologist at the Finley Hospital. 
When Henry Albert agreed to become director of the State Bacteriological Laboratory in 1904, he clearly hoped that he and his staff would have time to perform original research as well as carry out the tests required by the State Board of Health. Some of the university's medical faculty had pursed research projects and publications ever since the Medical Department had opened in 1870 , but teaching duties, hospital work, and private practice consumed much of their time. Until the 1910s, the Medical Department and University Hospital concentrated on equipping laboratories for teaching students and for performing diagnostic tests. The laboratories could also be used for research, especially when research primarily meant compiling and discussing clinical cases, but there was relatively little emphasis on laboratory research as such. ${ }^{65}$ The Bacteriological Laboratory, in contrast, had a trained staff that could be put to work on research during lulls in their routine tasks. Albert himself was an enthusiastic researcher. Between 1904 and 1907 he published 14 articles, 5 of them in national journals. In 1908, he edited a volume of the Bulletin of the State University of Iowa, which he intended as the first of a series displaying the Bacteriology Department's laboratory researches, although no further issues appeared. ${ }^{66}$

Bierring's and Albert's teaching, research, and service work on bacteriology at the University of Iowa, and the State Board of Health's reliance on bacteriological tests to identify and deal with epidemics, are clear examples of how a particular area of European laboratory medicine came to Iowa, entered medical education, changed how doctors diagnosed and treated disease, and offered research opportunities to trained practitioners. The advent and acceptance of other theories of disease causation, diagnostic technologies, and therapeutic innovations are much more challenging to track, especially to ordinary practitioners

65. L. W. Littig, "Diagnosis and Treatment of Typhoid Fever," IMJ 9 (1903), 343-47; idem, "Blood Pressure, Its Estimation and Significance," IMJ 19 (1913), 491-98; Walter L. Bierring, "A Report of Three Cases of Leukemia," IMJ 15 (1908), 249-56; Walter L. Bierring, "Diagnostic Control Experiments in Connection with Rabies," IMJ 7 (1901), 113-16.

66. Henry Albert, ed., Contributions from the Department of Pathology and Bacteriology, College of Medicine (including the Bacteriological Laboratory of the State Board of Health), in Bulletin of the State University of Iowa, n.s., vol. 1, no. 182 (Iowa City, 1908). This was the only volume published in this series. 
and their patients. The pages of Iowa's medical journals-the Iowa Medical Journal (1895-1914), a private, non-profit publication, and the Journal of the Iowa State Medical Society (1911-1961), owned by the state medical association-nevertheless provide glimpses into the experiences and opinions of regular physicians around the state, as well as news about colleagues and professional politics. ${ }^{67}$ By and large, in the decades from 1886 to 1928 (well before the implementation of strict peer review for research articles in post-World War II academic journals), state journals championed the basic equality of independent practitioners. According to the Iowa Medical Journal's editor in 1900, "These papers do not have to record some grand and impressive operation, nor some great idea that has come to you alone; but facts, only facts. ... One man don't [sic] hold an edge over another, just because he has written more papers or can report more cases, or is reputed to have a larger practice." ${ }^{\prime \prime 8}$

Some contributors' accounts do mark the transition of major twentieth-century discoveries from the laboratory into common medical practice. In 1903, for example, Dr. J. Rudis-Jicinsky of Cedar Rapids detailed the knowledge required to use $x$-ray equipment properly for diagnosis and treatment in the doctor's office. Dr. Edwin Winnett of Des Moines discussed his "spectacular" experience with injections of insulin into diabetic patients. His first case dates from mid-February 1923, only a few weeks after Eli Lilly had started to distribute small quantities of its purified product for clinical trials outside of Toronto and a few other major medical centers. ${ }^{69}$ Other accounts illustrate

67. Dr. J. W. Kime edited and published the Iowa Medical Journal (IM)), the costs of which were covered by subscriptions. The Iowa Medical Society started the Journal of the Iowa State Medical Society (IISMS) in 1911, and purchased the Iowa Medical Journal in 1914. In 1961 the JISMS was renamed the Journal of the Iowa Medical Society and, in 1984, became Iowa Medicine, which continues to the present as the primary publication of the Iowa Medical Society.

68. "The Medical Society," IMJ 6 (1900), 434.

69. J. Rudis-Jicinsky, "The Roentgen Ray in Diagnosis and Therapy," IMJ 9 (1903), 173-77; Edwin B. Winnett, "The Treatment of Diabetes with Insulin," JISMS 13 (1923), 325-27. For Campbell Howard's arrangements with Flexner for a $\$ 10,000$ grant that funded the University of Iowa's participation in Lilly's pilot studies of insulin in 1923, see Anderson, Internal Medicine, 35. Anderson reports that Howard trained 30 physicians in insulin treatment and treated 144 diabetics during that year. 
Iowans' encounters with newly discovered disorders. Early in 1914, for example, Dr. William Rendleman, a practitioner in Davenport, bemoaned the prevalence of hypertension, the "disease of modern civilization" recently revealed by the introduction of easy-to-use instruments for measuring blood pressure. As insurance companies increasingly required medical examinations before supplying life insurance, physicians started to find hypertension among people who had no symptoms of ill health. They were the lucky ones, Rendleman noted, because they could make changes well before the onset of trouble. "Overeating, rapid eating, the drinking of alcohol and smoking should be stopped. Habits should be regular regarding eating, sleeping and work. If the patient leads a sedentary life he should carry out moderate systematic exercise. Vacations to bring about complete relaxation should be insisted upon. ... Cereals, green vegetables, fresh fruits and vegetable purees are to be taken principally." Many Iowa physicians no doubt echoed this advice over the next decades as anecdotal evidence in favor of Rendleman's prescription accumulated. ${ }^{70}$

On the other hand, some Iowa practitioners also expressed their frustration with reports of new devices and new treatments. In the discussion of a paper by Dr. W. J. Findley on "The Present Status of Serum Treatment," given in 1910, Dr. Edward Edgerly of Ottumwa observed, "While I use the microscope and culture tube I do not class myself as a laboratory worker"; looking at complex drawings of cells gave him "a buzz" in his head. He wanted to know what each specific serum treatment "is good for and how to use it and to what extent we will be failing in our full duty to our patients if we do not use them." There had been major disappointments as well as successes with serumbased antitoxin-like treatments for infectious diseases, and Edgerly evidently hoped for clear-cut answers that he could use in his practice. He did not get them that day; as Findley had ex-

70. W. H. Rendleman, "High Blood Pressure," JISMS 3 (1913), 427, 432; Martin I. Olsen, "Present Day Needs in an Examination for Life Insurance," JISMS 14 (1924), 287-94; Audrey B. Davis, "Life Insurance and the Physical Examination: A Chapter in the Rise of American Medical Technology," Bulletin of the History of Medicine 55 (1981), 392-406; John H. J. Upham, "The Hypertension Syndrome in General Practice," JISMS 15 (1925), 286-93. 
plained in his paper, all serum treatments were "yet in the experimental stage" even though practitioners around the United States were using them. ${ }^{7}$

Edgerly's desire for straight answers about serum treatments illustrates a number of tensions between the medical sciences and the practice of medicine in the first decades of the twentieth century. Busy physicians not only had to find ways to keep up with new discoveries, tools, and treatments as more and more of them were announced by researchers and marketed by drug and products companies, but also to decide how to evaluate the range of claims made in the name of science. In 1907 Dr. E. Hornibrook advised his colleagues to spend at least two hours every evening studying medical periodicals and books and to wait until others reported on their clinical experiences with new treatments before adopting any of them. ${ }^{72}$

Access to new medical journals and books was itself a problem, however. The Iowa State Library agreed to provide a small medical reading room in Des Moines in 1913, which was first filled by donations from the Iowa Medical Society, the library of Drake's Medical Department when it closed, and gifts from individual physicians. It had no separate librarian or budget until 1919, when the state legislature made a small appropriation. When it began, the medical department of the State Library was the first in the nation to include its collections in its traveling library services and to loan books by mail to any physician in the state who requested them. ${ }^{73}$

To keep practitioners up to date, the Iowa Medical Society urged its constituent county societies to offer informative monthly programs and to invite outside specialists to hold demonstration clinics. Physicians could also seek additional educational experiences, such as the bacteriological course that Walter

71. W. J. Findley, "The Present Status of Serum Therapy," IMJ 17 (1910), 72-78, followed by discussion comments, including those of Edward Edgerly and Walter Bierring, 79-81.

72. E. Hornibrook, "Medical Education and Some Needed Legislation," IMJ 13 (1907), 425-27.

73. Jeannette Dean-Throckmorton, "History of the Iowa State Medical Library," in One Hundred Years of Iowa Medicine, 430-36. The JISMS regularly announced new acquisitions. See, for example, "Medical Library," JISMS 13 (1923), 119. 
Bierring offered at the University of Iowa from 1895 to 1901 or the surgical sessions advertised by Chicago hospitals in the early 1900 s. $^{74}$ In 1917 the University of Iowa's Medical Department began to offer summer courses specifically for general practitioners. "The clinical course will be of a very practical character," the 1917 announcement promised, "emphasizing the most modern methods in both clinical and laboratory diagnosis and treatment." ${ }^{\prime 75}$ In those years, the vast majority of physicians worked in solo private practices, however, so finding the time and the money to spend four weeks in Iowa City was probably prohibitive for many of them. Such opportunities were strictly voluntary; formal continuing medical education was not required by the Iowa Board of Medical Examiners for license renewals until 1978. ${ }^{76}$

In transferring results from the laboratory to the bedside, researchers found that clinical applications of some treatments were not only difficult to assess but also could have unfortunate effects on some people. For the most part, from the 1890s to the 1940s, clinicians evaluated new therapies based on their own bedside observations or those collected from other physicians' accounts. The profession was just beginning to consider seriously the methodological problems inherent in what would later be termed "anecdotal" data, even though practitioners knew quite well, at least intellectually, that a few cases with good or poor results demonstrated practically nothing about the efficacy of a treatment. It was all too easy to accept a drug or device that promised relief. "Many physicians forget their scientific training," Dr. T. H. Glenn cautioned in 1915, "and allow themselves to be imposed upon by [sales] agents" who just wanted to sell their companies' products."

74. "The Surgical Mecca," IMJ 10 (1904), 466; [untitled editorial], IMJ 13 (1907), 607; "Reports from County Societies," IMJ 13 (1907), 609-13; E. B. Brown, "The Scientific Spirit in the County Society," JISMS 1 (1911), 134-36; A. P. Stoner, "Facing the New Day in Medicine," JISMS 13 (1923), 79-83; "President's Message," JISMS 18 (1928), 405.

75. "Medical Summer Courses at the State University," JISMS 7 (1917), 122; Don Griswold, "State University News Items," JISMS 11 (1921), 446; Don M. Griswold, "Iowa State University News Notes," JISMS 13 (1923), 396.

76. "Continuing Medical Education Requirements," Iowa Board of Medical Examiners, www.docboard.org/ia/ContEd.htm (accessed 8/10/2004).

77. T. H. Glenn, "The Laboratory as an Aid to Diagnosis," IISMS 5 (1915), 373. 
The federal government, moreover, was also just beginning to regulate the commercial quality of vaccines and antitoxins (under the Biologics Control Act of 1902) and to forbid manufacturers from distributing "misbranded" drugs under the first Pure Food and Drug Act (1906). ${ }^{78}$ Warnings about the dangers of some new therapies had to make their way through the medical literature and conversations at meetings of medical societies. Bierring, in the discussion of serum treatments in 1910, for example, told the audience that "there is introduced into the nomenclature a new name, that of anaphylaxis, meaning overstimulation or over-sensibility," because a few people had reacted so drastically when injected that they died. ${ }^{79}$

Effective use of new diagnostic tests and devices could also be challenging, especially if a test could produce false positives (indicating the presence of a disease that was not actually there) or false negatives. Some tests required great care in how and when the physician obtained the sample from the patient, as well as in how accurately the test was carried out. ${ }^{80}$ Where the need for bacteriological tests for major infectious diseases had clearly fallen under the umbrella of state responsibilities for public health, diagnostic tests for other conditions, such as the examination of blood smears for evidence of anemia, or of urine for diabetes and other metabolic disorders, did not. In the 1890s to late 1910s, physicians in Iowa, especially those in small towns, either had to do their own laboratory work or do without.

In 1914 Henry Albert and Dr. Mildred Sheetz, one of his assistants, prepared a "model laboratory for the general practitioner" for a display at the annual meeting of the Iowa State Medical Society held in Sioux City. Their model required 64 square feet, fitted cabinets and specialized work surfaces, microscope,

78. Harry M. Marks, The Progress of Experiment: Science and Therapeutic Reform in the United States, 1900-1990 (New York, 1997), 25-47, 74-75.

79. Walter Bierring, discussion following Findley, "Present Status of Serum Therapy," 80.

80. H. A. Minassian, "The Diagnosis of Typhoid Fever," IMJ 6 (1900), 687-93; T. H. Glenn, "The Laboratory as an Aid to Diagnosis," JISMS 5 (1915), 372-75; "Defective Laboratory Reports," JISMS 6 (1916), 481; J. Hertzberg, "Some Points in the Preparation of Material for Laboratory Examination," JISMS 15 (1925), 237-40. 
centrifuge, sterilizer, hemacytometer, blood pressure apparatus, laboratory glassware and instruments, and at least 55 reagents and media. That was the minimum required for the tests that the general practitioner could do "at home," not for the advanced tests, such as the Wasserman test for syphilis, that still required specialists to perform. Albert and Sheetz estimated that such a laboratory would cost between $\$ 175$ and $\$ 300$ to equip (including the furniture, but not construction) ${ }^{81}$ At that time, the general practitioner might charge a patient one dollar for an office visit and two dollars for a home visit in town, while an "obstetric case, uncomplicated, not over 6 hours" cost fifteen dollars. Dr. W. L. Allen of Davenport estimated that a general practitioner needed to have "from ten to twenty visits each day" just to make ends meet-if patients actually paid their bills, which perhaps happened about half of the time. ${ }^{82}$ A \$200 investment in a laboratory was thus a considerable sum, even considering the income it might generate, since general practitioners had to do all of the work themselves.

Drs. Albert and Sheetz of course recommended that physicians in large enough towns combine their efforts and open a common laboratory staffed by a trained assistant or "cooperate with the city board of health laboratory" if one existed. ${ }^{83}$ How many general practitioners actually installed their own laboratories or shared one in the late 1910s is unknown, but the number of diagnostic tests requiring laboratory skills increased so rapidly that by the late 1920 s it is likely that the enthusiasm for do-it-yourself work had paled considerably. ${ }^{84}$ Dr. Frederick G.

81. "A Model Laboratory [editorial]," JISMS 3 (1914), 759; Henry Albert and Mildred Scheetz, "Model Laboratory for the General Practitioner," JISMS 3 (1914), 742-57.

82. J. N. McCormack, "Medical Economics-A General Plan for a Schedule of Medical Fees," IMJ 15 (1909), 393; W. L. Allen, "Our Profession Needs to Revolutionize Its Business Methods," IMJ 15 (1909), 394-97.

83. Albert and Scheetz, "Model Laboratory," 743-44. The State Board of Health certified hospital laboratories equipped with enough suitable equipment and skilled staff to act as branch laboratories of the State Bacteriological Laboratory.

84. Henry E. Tuley, "Aids to Diagnosis in Medicine," JISMS 13 (1923), 97-104; Frederick G. Murray, "The Diagnostic Net-Medical Viewpoint," JISMS 16 (1926), 55-57; Paul A. White, "The Diagnostic Net-Surgical Viewpoint," JISMS 16 (1926), 159-64. 
Murray of Cedar Rapids noted in 1926 that personal laboratories were not for the general practitioner but for the specialist, who "needs the laboratory for his own problems of treatment, diagnosis and prognosis in baffling critical cases or for private research in his specialty. ${ }^{\prime 85}$

Bacteriology and the other laboratory sciences reshaped medicine by changing not only physicians' understanding of the causes of certain diseases, but also their relationships with patients and their professional responsibilities. The laboratory did not displace practitioners, but it did start to reduce their complete clinical freedom when they had to rely on a laboratory test done by someone else to make a diagnosis. Keeping up with the clinical significance of laboratory discoveries and the claims for new tests and treatments further challenged individual doctors' abilities to manage their time, resources, and priorities. Between the late 1880 s and the late 1920 s, local and state medical societies provided opportunities for physicians to observe the effects of science on medical practice. In those decades, as well, doctors attended to the gradual transformation of hospitals into ostensible centers for scientific medicine, a change not entirely welcomed by the patients or practitioners in rural and small-town Iowa.

\section{Hospitals}

In the years between 1890 and 1930, hospitals acquired the status as places for science rather than refuges for the poor. In 1886 , general hospitals were places for the poor to go for medical attention and nursing care, largely supported by charity; the state funded only the asylums for the mentally ill and incapacitated, whose families could not cope with them. Most surgeries took place in the patient's home, with a room prepared by taking out furniture, removing dust-collecting rugs and curtains, and cleaning thoroughly. By 1930, the hospital revolution was well under way. Although half of the women in the United States still gave birth at home, surgery-except for emergencies-took place in hospitals, and more and more patients with serious illnesses were directed to hospitals for skilled nursing

85. Murray, "The Diagnostic Net: Medical Viewpoint," 57. 
attention, controlled diets and medication schedules, and more frequent contact with specialists. Hospitals developed alongside new technologies for diagnosis and treatment: x-ray departments, diagnostic and pathological laboratories, and specialized operating rooms with electric lights, sterilizers, and autoclaves. ${ }^{86}$ Instead of a place of dread and stigma, the hospital increasingly became a place of hope and skill.

The 21 hospitals founded in Iowa by 1890 primarily consisted of state institutions for the insane and charitable refuges for the poor run by religious organizations or community philanthropy (see table 2). Dr. A. L. Yokum opened the first known private hospital in Iowa in Lucas in 1892. It had four beds. The early private hospitals, some of which limited their work to childbirth, were essentially boardinghouses that brought patients close to the physician and to some skilled nursing care. Yet they marked a turning point, for they charged for their services and provided facilities suitable for a middle-class clientele. Hospitals funded primarily by charity-and the University of Iowa Hospital, supported by taxes-soon followed suit, creating private and semi-private rooms for paying patients in contrast to the wards for the less well off. ${ }^{87}$ By the early 1910 s, most of the non-profit hospitals depended for part of their income on paying patients, subsidies from local governments, and interest from investing their endowments and donations. As these hospitals grew in the 1920s, they could no longer be run entirely by well-meaning nursing nuns or volunteer lay boards; business managers started to join their staffs.

From the beginning, private hospitals were for-profit enterprises, although the profits might be meager. The convenience for the physician, as well as the health benefits for the patient, however, encouraged doctors to form partnerships in these small businesses. Some of these became prominent and innovative institutions. A group of physicians opened Park Hospital in

86. Joel D. Howell, Technology in the Hospital: Transforming Patient Care in the Early Twentieth Century (Baltimore, 1995); Charles E. Rosenberg, The Care of Strangers: The Rise of America's Hospital System (New York, 1987); Rosemary Stevens, In Sickness and In Wealth: American Hospitals in the Twentieth Century (New York, 1989).

87. Levey et al., Rise of a University Teaching Hospital, 31. 
Mason City in 1909, for example, and by 1911 they needed a new building. Their new premises included offices for each of the practitioners, a shared secretary, a clinical laboratory, an $\mathrm{x}$ ray department, a training school for nurses, two operating suites, and an elevator. Several of the private and semi-private rooms had in-suite private bathrooms, and a system of dumbwaiters carried food and supplies to the upper floors. ${ }^{88}$ Many Iowa physicians looked askance at these group enterprises, as they entangled independent practitioners in financial and professional relationships that could lead to conflicts and compromises over patient care. ${ }^{89}$

As early as 1902, some observant Iowans believed that charity and private enterprise would not suffice to fill the population's need for hospital facilities, especially in rural areas. In 1906 the legislature authorized city councils to establish municipal hospitals, if city voters passed a special tax measure to fund them. ${ }^{90}$ Efforts to enable counties to fund hospital construction with a special tax levy failed until the 1908-09 session of the General Assembly, however. In that year, Dr. Elbert E. Munger of Spencer felt so strongly about the bill that he "forsook his business" for two months to go to Des Moines, where he "pushed the bill in both houses, at the hotels and everywhere else. ${ }^{\prime \prime 11}$ The Munger Act allowed counties to raise a hospital tax if enough citizens signed a petition to get the issue before the county as a referendum, which then had to meet complicated voting requirements. By the end of 1910, the people of 11 counties were working on the petition and referendum process with the support of farmers' institutes and the Iowa Federation of Women's Clubs. ${ }^{92}$

Within a few years, the Munger Act had received national attention as a model for local hospital initiatives, and Indiana and Kansas had copied it. ${ }^{93}$ By 1912, however, only two counties,

88. C. F. Starr, "Park Hospital," IISMS 3 (1913), 26-28.

89. Elbert E. Munger, "Oration in Surgery," JISMS 14 (1924), 100-101.

90. 1907 Code of Iowa, Supplement, Title V, chap. 4, 741o-741t.

91. "The County Public Hospital," IMJ 15 (1909), 559; "Dr. E. E. Munger, Spencer, Iowa," IMJ 15 (1909), 560-61.

92. "The County Hospital," IMJ 16 (1910), 639.

93. "Counties," IMJ 17 (1911), 610; "County Hospital Laws," IMJ 19 (1913), 528;

"More Rural Hospitals Needed," JISMS 16 (1926), 466-67. 
Washington and Jefferson, had actually approved such referenda; theirs were the only county hospitals funded through the provisions of the Munger Act until 1926. ${ }^{94}$ In 1913 the legislature passed a separate act allowing county supervisors to segregate the poor with tuberculosis. If they stayed under certain cost limits, moreover, they could acquire a building for a tuberculosis hospital for the indigent without needing to submit the expense to a countywide vote. ${ }^{95}$ Counties could also subsidize patients in a county ward in private hospitals. By 1928, five counties had established sanatoria, and three more had built county general hospitals. All of these were in fairly populated areas, however, not, as Munger had envisioned, in the rural districts that increasingly needed them.

The more that hospital care was seen as a necessity, not a disgrace or a luxury, the more critical seemed its absence in Iowa's rural areas and small towns, which did not have the resources or willingness to support hospitals by charitable donations or by taxes. Counties and towns appointed physicians to serve as health officers who took care of the very poor; others just had to manage. But when the very poor needed hospitalization, the counties had to pay for their transport to the closest hospital that could accept the indigent. The Haskell-Klaus Law of 1919 expanded the popular and successful Perkins Act of 1915 to allow counties to send their indigent adult as well as children patients to the University of Iowa Hospital, where the state would be responsible for the costs, lifting a burden from county budgets - and from physicians who had treated the very sick poor with little hope of having their bills paid. ${ }^{96}$

Providing for very sick indigent patients in Iowa City certainly helped county budgets and the University Hospital's need for patients, but it did not address other aspects of access to health care. Where were people to go for emergency surgery when they could not travel long distances? Where were rural women to go if they wanted to heed all the new advice and

94. Elbert E. Munger, "Hospitals and the Health Problem-With Special Reference to the Needs of Rural America," Sixteenth Annual Report of the State Board of Health ... for the Fiscal Period Ending June 30, 1912 (Des Moines, 1913), 276-85. 95. "The Care of Tuberculous Poor," IMJ 19 (1913), 529.

96. Levey et al., Rise of a University Teaching Hospital, 62-67. 


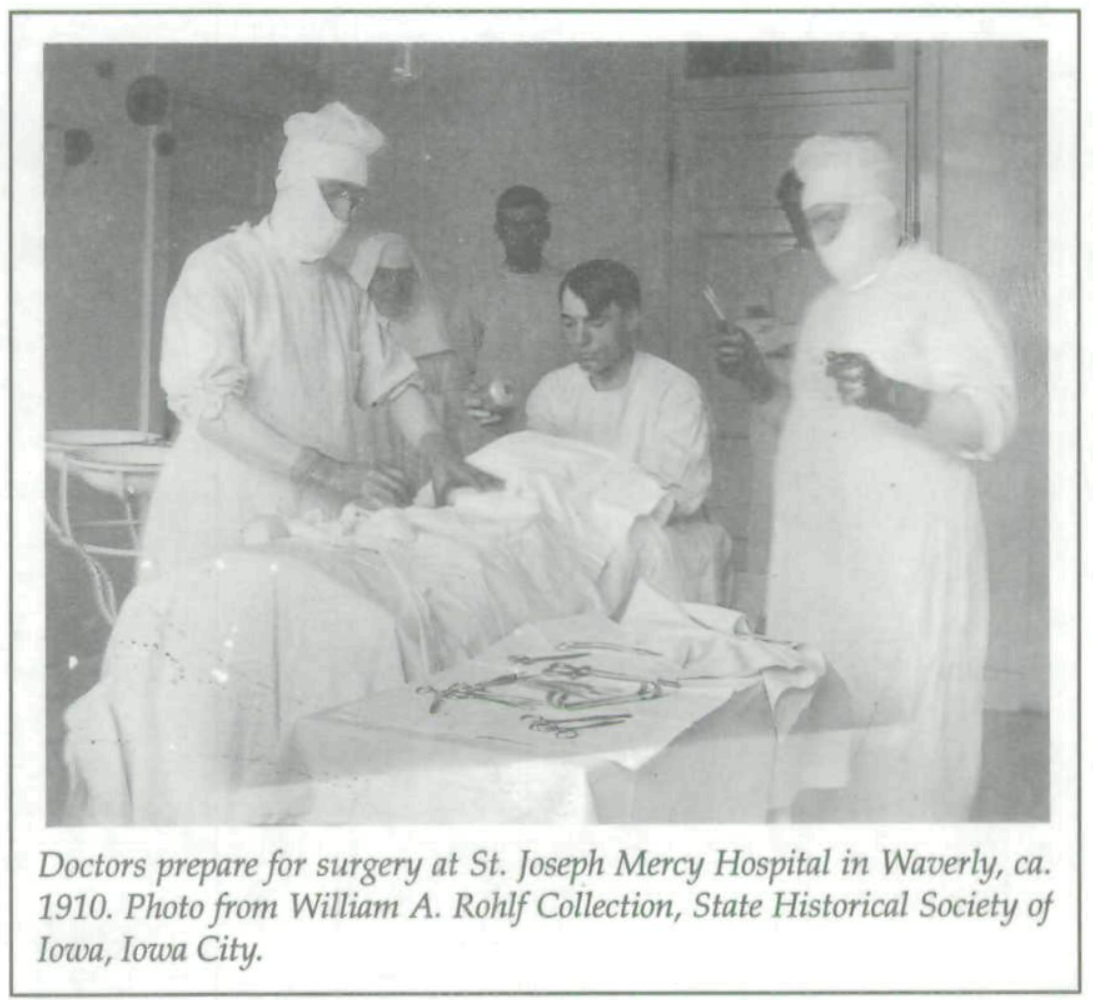

have their babies in a hospital? Going to a hospital miles and miles away from home put financial and emotional stresses on patients and their families that could outweigh physicians' arguments about the medical necessity for inpatient care. Despite the growth in the number of hospitals in Iowa between 1890 and 1930 (see table 2), their uneven geographic distribution remained a major problem in the state.

As expectations about hospital care changed, moreover, medical observers became concerned not just about the distribution of hospitals but also about the quality of existing facilities. In 1911, an editorialist in the Journal of the Iowa State Medical Society complained that "as [hospitals] now stand, most of them are little better than boarding houses for the sick. It is sometimes pathetic to hear the boastful claims of the Board of Managers or of the Superintendent on showing a very good building but destitute of a laboratory and of any scientific apparatus or means of diagnosis or investigation of any kind." Every hospital should 
TABLE 2

HOSPITALS IN IOWA, 1890 AND 1930

\begin{tabular}{|l|c|c|}
\hline Primary funding and affiliation & $\mathbf{1 8 9 0}$ & $\mathbf{1 9 3 0}$ \\
\hline Religious and charitable: Total & 12 & 65 \\
\hline Catholic & 5 & 29 \\
\hline Protestant & 2 & 15 \\
\hline Endowed and charitable donations & 5 & 19 \\
\hline Fraternal & & 2 \\
\hline & & \\
\hline Private individual or partnership businesses: Total & 3 & 75 \\
\hline Private - Physician-owned & & 54 \\
\hline Private - Other groups & 2 & 20 \\
\hline Railroad consortium & 1 & 1 \\
\hline & & \\
\hline Tax-based institutions: Total & 6 & 35 \\
\hline Federal - Military and Veterans & & 2 \\
\hline State - Insane, "feebleminded," and epileptics & 5 & 6 \\
\hline State - General & & 2 \\
\hline State- Tuberculosis & & 2 \\
\hline County - Insane & 1 & 3 \\
\hline County - General & & 5 \\
\hline County - Tuberculosis & & 4 \\
\hline Municipal - General & & 8 \\
\hline Municipal - Isolation & & 3 \\
\hline & & 175 \\
\hline Total & & \\
\hline & & \\
\hline
\end{tabular}

SOURCES: Clyde A. Boice, "Hospitals in Iowa," in One Hundred Years of Medicine in Iowa (Iowa City, 1950), 371-419; American Medical Directory (1931). The data do not include hospital facilities within other institutions, such as the infirmary in the Iowa State Penitentiary. 
have "a well equipped clinical laboratory, an x-ray outfit and a trained anesthetist." A hospital, according to another editorial later that year, should be "a center of genuine medical and surgical work; where the latest and most scientific methods could be employed for the relief of suffering and disease. ${ }^{\prime \prime 7}$ These comments centered on patients' needs for up-to-date equipment and attitudes; a decade later the poor quality and distribution of hospitals were also partly blamed for the declining number of physicians in rural areas. ${ }^{98}$ Without a decent hospital and diagnostic laboratory, the newly minted medical practitioner would have to refer his or her paying patients to physicians who had settled in urban areas, where they could also enjoy the social benefits of town and city life.

The deficits of Iowa's hospitals also affected the status of internship training in the state. In 1910 the American Medical Association started to recommend that all medical graduates spend a postgraduate year in a hospital for general training, rotating through the wards and working with a wide range of clinicians, before being licensed to practice medicine. This idea was slow to be adopted, largely because in many areas, including Iowa, too few hospitals had the beds, staff, and facilities to make a year working in them educationally useful. ${ }^{99}$ The Iowa Board of Medical Examiners decided, in March 1917, that all students who entered medical school after July 1, 1919, would be required to complete a year's internship after graduating in order to apply for a license to practice. This decision, made six years before the requirement would go into effect for the students graduating in 1923, anticipated the additional skills that physicians needed to acquire beyond their medical school education and acknowledged the growing importance of hospitals in the work of all doctors. ${ }^{100}$ In 1919 the AMA Council on Medi-

97. "The Hospital Situation," JISMS 1 (1911), 81; "The Hospital Situation," JISMS 1 (1911), 130.

98. "Medical Coordination and Cooperation," JISMS 11 (1921), 262.

99. W. Woodbridge, "Oration on Medicine," IMJ 17 (1910), 174; "Improvements at Agatha Hospital," JISMS 5 (1915), 241; Ludmerer, Learning to Heal, 79.

100. Minutes of Meetings, Board of Medical Examiners, 3/15/1917. In 1926 Dr. Fuller, appointed as secretary to the board in 1925, questioned the legality of the board's internship requirement (Minutes, 1/6/1926). Every previous sub- 
cal Education issued its statement on "Essentials for Approved Internships," which listed the requirements that hospitals had to fulfill in order for the council to accredit them, and the University of Iowa College of Medicine encouraged its graduates to complete internships, even though they were not yet required for licensing. In 1925, nevertheless, only seven of the approximately 70 general hospitals in Iowa met accreditation requirements, which included having at least 50 beds, autopsy facilities, a range of cases in surgery, medicine, obstetrics, and ophthalmology, and a properly equipped diagnostic laboratory. At least half of the graduating class that year had to find out-of-state internships to meet the state's basic licensing standards. ${ }^{101}$

As expectations for hospital care for the very sick and injured increased, physicians had to establish connections to hospitals near them or turn their patients over to others. In 1928 Dr. William F. Amdor, a general practitioner in a country practice, complained that he merely served as a "first-aid station" for minor illnesses and injuries, as people seemed to believe that they needed hospitals and specialists for anything serious. ${ }^{102}$ Amdor's frustration aptly illustrates the flip-side of the progress that Iowans were about to celebrate with the opening of the new general hospital and medical laboratories in Iowa City. The more that scientific studies revealed about the underlying causes of diseases and pointed to ways to prevent them, the greater the need for people to consult physicians before they became seriously ill, or even when they seemed to be reason-

stantive change in licensing requirements decided by the board had been taken to the General Assembly for inclusion in revisions to the licensing act, but this one had not. It was belatedly included in legislation passed in 1927, much to the puzzlement of the anonymous author of the news note in the JISMS, who was surprised that Iowa had not required internship before. "A Year's Internship Required of Applicants for License to Practice Medicine in Iowa," JISMS 17 (1927), 103.

101. Ludmerer, Learning to Heal, 79-81; Starr, Social Transformation of American Medicine, 167; Bulletin of the State University of Iowa, 1918-1919 (Iowa City, 1919), 335; Levey et al., Rise of a University Teaching Hospital, 61. In 1921 there were 70 general hospitals in Iowa, not including residential asylums, prison and detention hospitals, or sanatoria. "Hospital Report," Journal of the American Medical Association 80 (1921), 536-38.

102. William F. Amdor, "A First Aid Station in the Country," JISMS 18 (1928), $44-49$. 
ably healthy. But doctors cost money. People would have to be convinced.

\section{The Health of the People: Babies, Children, and Mothers}

Laboratory tests for diphtheria, tuberculosis, typhoid, and, with the Wasserman reaction, syphilis, confirmed clinicians' knowledge that these diseases sapped the strength of Iowans in the early twentieth century. Tuberculosis had long been a major killer. Bacteriological work revealed not only the extent of its inroads into the population, but also its transmission via human sputum and cow's milk. ${ }^{103}$ Throughout the nation, various groups lobbied to pass laws against public spitting, to create sanatoria for the isolated care of infectious patients, and to put muscle into the regulation of the milk supply. ${ }^{104}$ In 1906 the Iowa legislature passed a bill to fund a tuberculosis sanatorium at Oakdale, near Iowa City, which opened in $1908 .{ }^{105}$ Later enabling legislation allowed counties and municipalities to create their own tuberculosis sanatoria or to designate part of an existing hospital as a tuberculosis ward. The State Board of Health and various other Iowa organizations worked to educate citizens about the dangers of tuberculosis and how it was spread, but it was very difficult to detect infectious people before serious symptoms sent them to a doctor. ${ }^{106}$

103. "Identity of Human and Bovine Tuberculosis," Iowa Health Bulletin 18 (1904), 10-11.

104. For an introduction to the national picture, see Barbara Bates, Bargaining for Life: A Social History of Tuberculosis, 1876-1938 (Philadelphia, 1992); Barbara Gutmann Rosenkrantz, "The Trouble with Bovine Tuberculosis," Bulletin of the History of Medicine 59 (1985), 155-75; "Anti-Spitting," Iowa Health Bulletin 23 (1909), 19.

105. For an example of early agitation for a public tuberculosis sanatorium in Iowa, see J. F. Richardson, "President's Address [to the Iowa Union Medical Society]," IMJ 6 (1900), 564. Iowa physicians lobbied for a sanatorium at least from 1904. See E. Luther Stevens, "The Tuberculosis Sanatorium Bill," IMJ 10 (1904), 127-28; 1907 Code of Iowa, Supplement, chap. 11C.

106. The Iowa legislature funded a salary for a "State Lecturer on Tuberculosis," under the State Board of Control, beginning in 1905. Aretas E. Kepford, who held the position for many years, traveled around the state lecturing to a wide variety of audiences. G. H. Sumner, "Aretas E. Kepford, State Lecturer on Tuberculosis," Iowa State Board of Health Bulletin 1 (1916), front matter. 


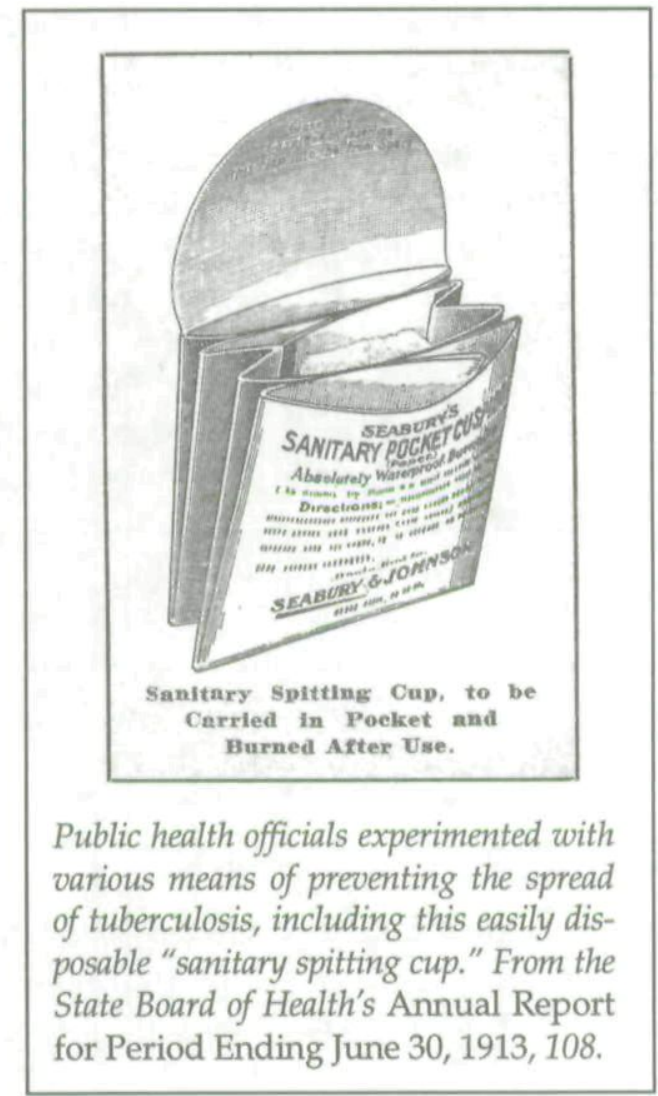

The problem of tuberculosis among animals was especially tricky in an agricultural state whose citizens had an enormous investment in stock. In 1908 Iowa already had nearly twice as many cattle and three times as many hogs as people. Estimates at the time put these animals' value at $\$ 1.82$ billion, with 2 percent of the swine, 2 percent of the beef stock, and 10 percent of the dairy cattle infected with tuberculosis-at least $\$ 8$ million worth of grazing incubators. Studies had already more or less convinced researchers that the infected hogs and beef cattle were not a major threat to human health, since the tuberculosis bacillus did not appear to survive slaughter and cooking, although these animals could infect each other through contact with fresh feces. Because it appeared as though hogs and beef cattle initially caught tuberculosis from dairy cattle, moreover, 
dealing with tubercular milk cows became the primary focus of both agriculturalists and public health experts anxious to eradicate the disease. ${ }^{107}$

The pronouncements of bacteriologists and the production of diphtheria antitoxin may have convinced Iowans to fund a State Bacteriological Laboratory in 1904, and even to let their children be injected with "horse juice" when suffering from diphtheria, but these signs of confidence in science did not translate into legislation and money for ridding the state's dairy cows of tuberculosis. In 1884 the state had created the office of the State Veterinary Surgeon, with the power to destroy cattle and horses carrying "contagious and infectious diseases" when a matter of "public safety."108 Actually doing so, however, was quite a different matter. The office of the State Dairy Commissioner was started in 1886 to prevent fraud in the making and selling of milk products, with particular attention to the problem of diluted milk and the use of imitation butterfat. The language covering "pure" milk was broadened in 1911 to forbid the use of milk "taken from an animal having disease, sickness, ulcers, abscess or running sore," but this change carefully avoided naming any particular disease. Neither cows nor milk had to be tested for any disease, so asymptomatic tubercular cows continued to provide milk for home and market. ${ }^{109}$

Dr. J. W. Cokenower, chair of the Iowa Medical Society's Committee on Public Policy and Legislation, summed up physicians' strong feelings about the political process that had resulted in the 1921 act for the "Eradication of Bovine Tuberculosis" after years of public health lobbying.

The advocates of better health laws in the past, have considered that human life was of more importance than that of farm animals, and have asked the legislature for pure milk for the children, and the request was turned down, but, when it was demonstrated that

107. J. W. Kime, "What Shall We Do with the Question of Animal Tuberculosis?" IMJ 15 (1908), 122-26; "Tuberculosis among Domestic Animals," Iowa Health Bulletin 18 (1905), 166-69; E. C. Schroeder, "The Unsuspected but Dangerously Tuberculous Cow," Iowa State Board of Health Bulletin 24 (1910), 38-52 (esp. fig. 2, p. 41).

108. 1885 Code of Iowa, chap. 189.

109. 1911 Laws of Iowa, chap. 113, sec. 4. 
tuberculosis in the herds, was killing off the pigs which drank the same class of milk furnished the children, then the legislature had no hesitancy in making an appropriation of $\$ 250,000$ to clean up the tuberculosis from the farm, in order to save the life of the pigs; and the U. S. Government provided yet another $\$ 250,000$, making $\$ 500,000$ for the two-year period.

A few days later the same legislature hesitated to appropriate an increase of $\$ 5,000$ to the board of control, making a total of $\$ 10,000$ for an educational campaign against the ravages of tuberculosis in the human family.

Part of the hefty appropriation for the 1921 act went to providing free testing, which could only be done by accredited veterinarians who used tuberculin controlled by the state Department of Agriculture. ${ }^{111}$ The bill authorized the department to "make an examination of any herd" at will. Most of the act, however, concerned two other means of inspection: (1) voluntary inspection of a herd at an owner's request; and (2) a complex process by which counties could start (and partly pay for) an eradication plan that could force cattle owners to comply. ${ }^{112}$ The economic interests of dairy farmers who wanted to be able to flourish certificates of tuberculosis-free herds joined with those of hog producers seeking less wastage among their swine to allow public health officers to hope that milk-borne tuberculosis might finally disappear. Thus, in 1924 the state finally required that all milk sold had to come from cows certified free of tuberculosis, although only skimmed milk (from 1913) and buttermilk (1924) had to be pasteurized, a process that was itself still controversial. ${ }^{113}$

110. "Report of Committee on Public Policy and Legislation," JISMS 11 (1921), 277.

111. 1924 Code of Iowa, chap. 129.

112. The famous Iowa "Cow War" of 1932 occurred when cattle owners suffering from the continuing economic depression briefly resisted mandatory testing and the destruction of their possibly tubercular cattle in Cedar County. Dorothy Schwieder, Iowa: The Middle Land (Ames, 1996), 257-59; Theodore Saloutos and John D. Hicks, Agricultural Discontent in the Middle West, 19001939 (Madison, WI, 1941), 437-41.

113. 1924 Code of Iowa, chap. 150, secs. 3076-77; Richard A. Meckel, Save the Babies: American Public Health Reform and the Prevention of Infant Mortality, 1850 1929 (Baltimore, 1990), 86-89. 
FIGURE 1

DEATH RATE FROM TYPHOID IN IOWA, 1905-1916

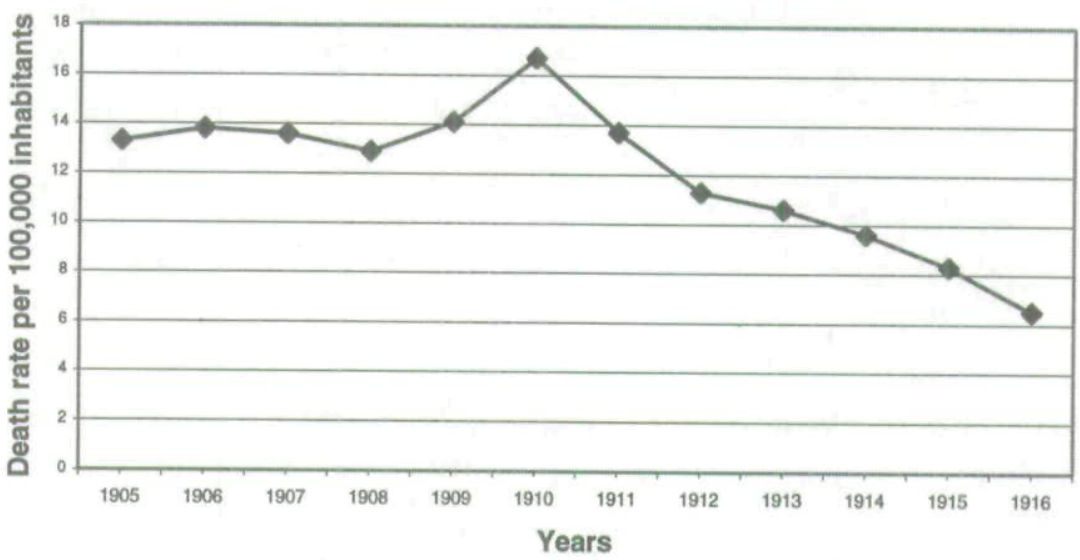

SOURCE: Max Levine and H. E. Middleton, "Some Observations on Typhoid Fever in Iowa," IISMS 8 (1918), 37.

The death rates from some of the major infectious diseases - diphtheria, tuberculosis, and typhoid, for example-did decline in Iowa between 1886 and 1928, as they did across the nation in those years. The data on death (and birth) rates for Iowa were unreliable for the years before 1923-24 - too many physicians, undertakers, and clerks failed to comply with the state's vital records laws-but even the incomplete numbers reveal the effects of improvements in urban sanitation, tuberculosis testing, antitoxins, and vaccines. (For example, see fig. 1 for the decline in typhoid death rates. $)^{114}$ For physicians concerned about public health, though, any deaths from tuberculosis, typhoid, or diphtheria were increasingly seen as tragic because they were preventable.

In the early years of the twentieth century, a closer examination of the state's death rates when broken down by age and causes had confirmed a high number of deaths of infants and

114. Max Levine and H. E. Middleton, "Some Observations on Typhoid Fever in Iowa," JISMS 8 (1918), 37-40; "Decline in Tuberculosis Death Rate" IISMS 14 (1924), 383; "Increased Death Rate in People of Middle Life" [reported from the Illinois Medical Journal, June 1914], JISMS 5 (1915), 243. 
young children in Iowa, compared to older children and young adults. ${ }^{115}$ High infant mortality and the vulnerability of the young to disease was a well-known feature of life before the twentieth century. During the nineteenth century, changing social conditions and values, especially among the middle classes, had led reformers to pay more attention to the condition of children, spurring movements for child labor laws and public schools. Physicians began to concentrate more on the diseases of infancy and childhood, increasingly convinced that mothers needed expert medical advice, and pediatrics had developed as a new medical specialty in the 1880 s. The trend to protect and save children gained momentum in the Progressive era, with both volunteer and professional groups championing the cause of child health. Activists and researchers formed the American Association for Study and Prevention of Infant Mortality (AASPIM) following a conference on the subject organized by the American Academy of Medicine in 1909. Members of the AASPIM helped to push for a federal agency devoted to all aspects of children's welfare. Enabling legislation finally passed Congress in 1912, and the Children's Bureau became part of the Department of Labor. Julia Lathrop, the bureau's first director, made reducing infant mortality a top priority. Unlike previous movements to reduce infant mortality, which concentrated primarily on poor, crowded areas of large cities and worked to improve sanitation and the supply of adequate milk, the AASPIM and the Children's Bureau believed that the most urgent task was to educate mothers in the proper hygienic care of their babies. ${ }^{116}$

In Iowa, the State Board of Health was an early advocate of the new "Save the Babies!" campaign, with its emphasis on educating mothers. In the 1911 spring issue of the Board of Health's bulletin, Guilford Sumner, the board's secretary, bluntly wrote that "something must be done to prevent the excessive mortality among children." He continued with advice on infant care that he hoped "the newspapers of our state will copy ... for the

115. "Deaths from Preventable Diseases and Deaths Reported in Iowa for the Year 1910," Bulletin of the Iowa State Board of Health 24 (1911), 80-82.

116. Molly Ladd-Taylor, Raising a Baby the Government Way: Mothers' Letters to the Children's Bureau, 1915-1932 (Brunswick, NJ, 1986), 6-7; Meckel, Save the Babies, 98-123. 


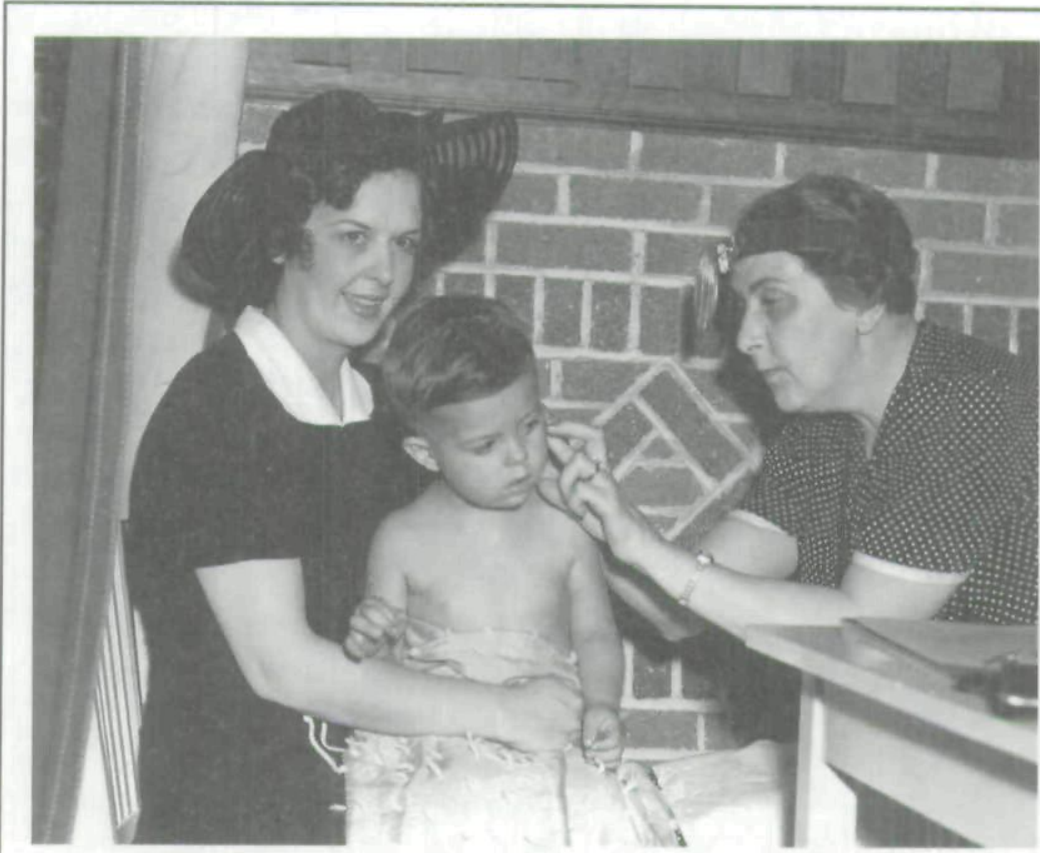

A health care worker examines a baby at the Iowa State Fair in 1936. Photo from State Historical Society of Iowa, Des Moines.

benefit of fathers and mothers." Sumner stressed that infants must be breast-fed if at all possible, but gave instructions on bottle-feeding for those who could not avoid it. "Remember that absolute cleanliness is necessary in all details of the feeding. Because some babies have lived through filth is no argument that yours will." He repeatedly urged mothers to consult their doctors at the first sign of diarrhea, especially in the summer: "It may not be too late." ${ }^{117}$

Diarrheal diseases were one of the major causes of death of infants and young children. Even without any laboratory-based connections to specific microbes at the time, disinfecting bottles and boiling water used for babies seemed vital. Throughout the 1910s and 1920s, the Board of Health continued to publish advice written specifically for pregnant women and mothers of

117. "Save the Babies!" Iowa State Board of Health Quarterly Bulletin 24 (1911), 106-9. This article was reprinted several times in the Bulletin. 


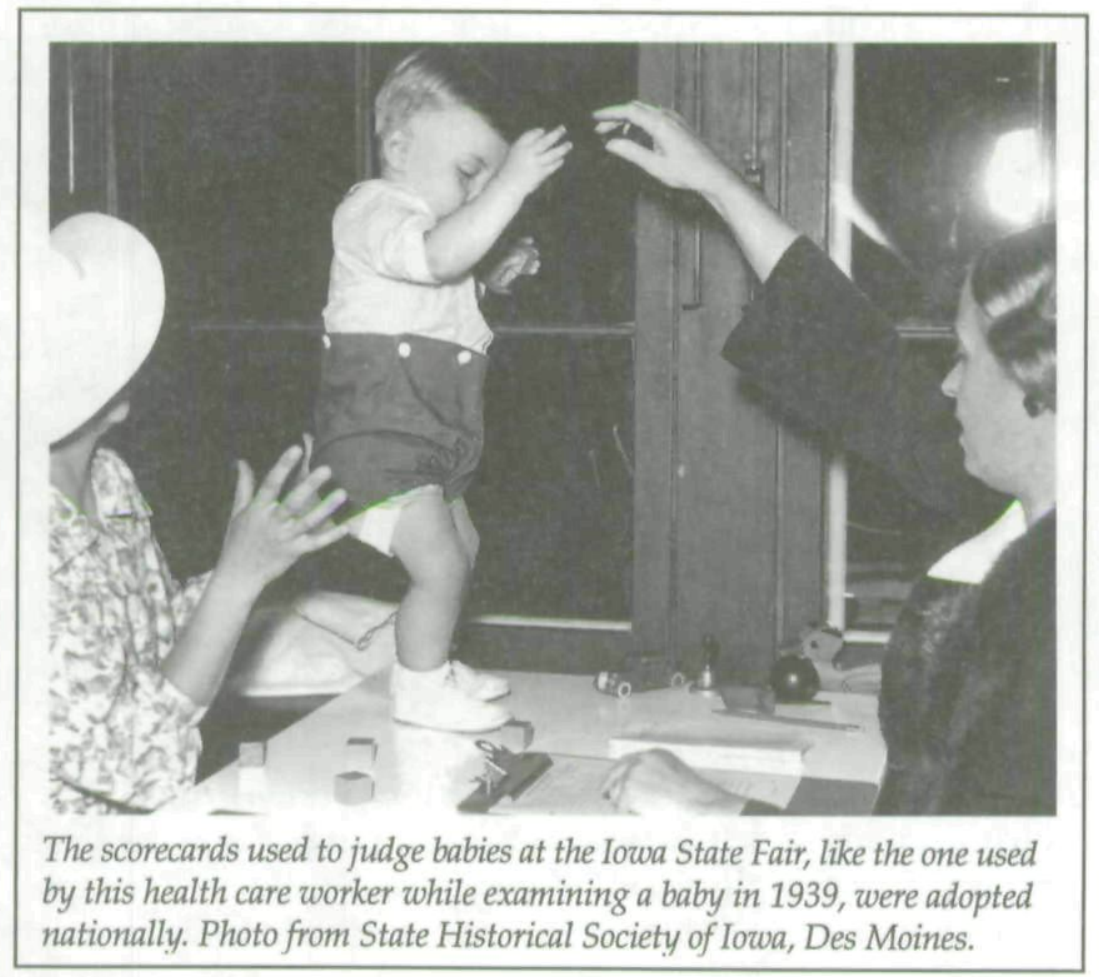

infants. Copies of pamphlets on those topics were provided free or for nominal cost by the Board of Health, the Children's Bureau, and other organizations. ${ }^{118}$

In 1911 two Iowa women, Mary T. Watts and Margaret Clark, M.D., had a truly innovative idea for increasing attention to infant health. For the "Women's Hour" section of the Iowa State Fair, they applied the idea of competitive livestock shows to human stock. Finding the "healthiest" - not the prettiest-baby provided an opportunity to instruct mothers, fathers, and potential parents about how to produce such glowing specimens of human beings. The Iowa idea was so popular that it spread quickly throughout the Midwest. Exhibits and lectures joined the program, but the highlight was the judging. With physicians presiding, assistants filled out scorecards that included informa-

118. Ladd-Taylor, Raising a Baby, 32-42; Bulletin of the Iowa State Board of Health 1 (1916), 43-53. 
tion on the child's family, diet, personality, and physical measurements. In 1917 the American Medical Association adopted the Iowa scorecard as a national model for such examinations. Physicians who participated in these contests spread the message that even healthy babies needed regular visits to the doctor and that mothers should look to them, not to relatives and neighbors, for advice about caring for their children. ${ }^{119}$

Iowa volunteers also started clinics where poor mothers could bring their babies to be examined by physicians who donated their time. Those doctors were clear that they would not treat the infants for free, but would refer the mother to a physician if her baby needed medical attention. Other initiatives aimed to have nurses and doctors inspect children in schools, again to find those who obviously needed medical care. ${ }^{120} \mathrm{Al}$ though sporadic at best, such heightened awareness of the needs of children, who were being redefined as particularly vulnerable and innocent members of American culture, contributed to the legislature's support for the Perkins bill in 1915.

That act allowed "any probation officer, overseer of the poor, regularly licensed physician or public school teacher" to provide a local judge with information on "any child under sixteen years of age suffering from a curable or remediable deformity or malady." If circumstances warranted, the child could then be "committed" to the University of Iowa Hospital for treatment paid for by the state. The Perkins bill, one of the first major acts of social welfare legislation in Iowa, helped to transform the relationship between the state's citizens and the University Hos-

119. Alisa Klaus, Every Child a Lion: The Origins of Maternal and Infant Health Policy in the United States and France, 1890-1920 (Ithaca, NY, 1993), 144-50; Mary T. Watts, "The Iowa Baby Health Contest," IMJ 20 (1912), 91-94; "The Baby Health Contest," IMJ 20 (1913), 483; "Iowa State Fair-Baby Health Score Card," JISMS 17 (1927), 297-98. See also Annette K. Vance Dorey, Better Baby Contests: The Scientific Quest for Perfect Childhood Health in the Early Twentieth Century (Jefferson, NC, 1999); and Marilyn Irvin Holt, Linoleum, Better Babies and the Modern Farm Woman, 1890-1930 (Albuquerque, NM, 1995), chap. 4, "Better Babies and Rural Health," 95-123.

120. "Baby Saving in Iowa," IMJ 20 (1914), 394; "Medical Inspection of Public Schools in Cities," IMJ 4 (1898), 183-87; "Medical Inspection of Schools," IMJ 17 (1910), 196 (re: inspections in Waterloo); Henry Albert, "Diphtheria Carriers and Medical Inspection of Schools," IMJ 18 (1912), 261-65; Laura Rockwood, "An Experiment in Child Inspection," JISMS 6 (1916), 123-24. 
pital. It made it possible for the university to secure the patients it needed to support clinical instruction for medical students, while providing the patients with the needed care and skills found in a teaching hospital. In 1919, state appropriations allowed the university to open its separate Children's Hospital on the west side of the Iowa River, in part due to the demand raised by the needs of "Perkins" children. ${ }^{121}$

Further support for child heath and welfare in Iowa came from a different direction in the 1910s. Vitalized by her participation in the National Congress of Mothers, Cora Bussey Hillis lobbied long and hard to have the state fund a research institute for the scientific study of children. Events kept derailing her project, including splits in women's organizations that were divided over the issue of woman suffrage, and conflicts with Carl Seashore, a prominent psychologist at the University of Iowa, over just what a child research institute should entail. Hillis and Seashore finally managed to compromise and, with Hillis's considerable efforts in Des Moines, in 1918 the General Assembly passed enabling legislation and a \$25,000 annual appropriation for the "Iowa Child Welfare Research Station" to be housed at the University of Iowa. ${ }^{122}$

Unlike so much work that had already been done on children, this institute was to be devoted to comprehensive scientific study of the "normal" child. Studies at the station encompassed physical measurements, psychological testing, projects on different kinds of learning and skill levels, along with attention to the nutrition, hygiene, and regular habits of the children involved in the station's play groups. The Iowa data contributed to national efforts to define the "normal" child both mentally and physically, constructing standards that were then used in ongoing discussions of what constituted the "abnormal" one. In contrast to the deterministic and reductionist hereditarian theories that tended to dominate the emerging field of childhood development, re-

121. "Provisions of the Perkins Bill Relating to the Care of Curable Deformities and Maladies in Children," JISMS 5 (1915), 390. "Perkins Law Has Benefitted 877 ," JISMS 7 (1917), 325 (quoted from an article by W. R. Boyd published in the Chicago Tribune).

122. Ginalie Swaim, "Cora Bussey Hillis: Woman of Vision," Palimpsest 60 (1979), 162-77. 
FIGURE 2

INFANT AND MATERNAL DEATH RATES IN IOWA, 1910-1930

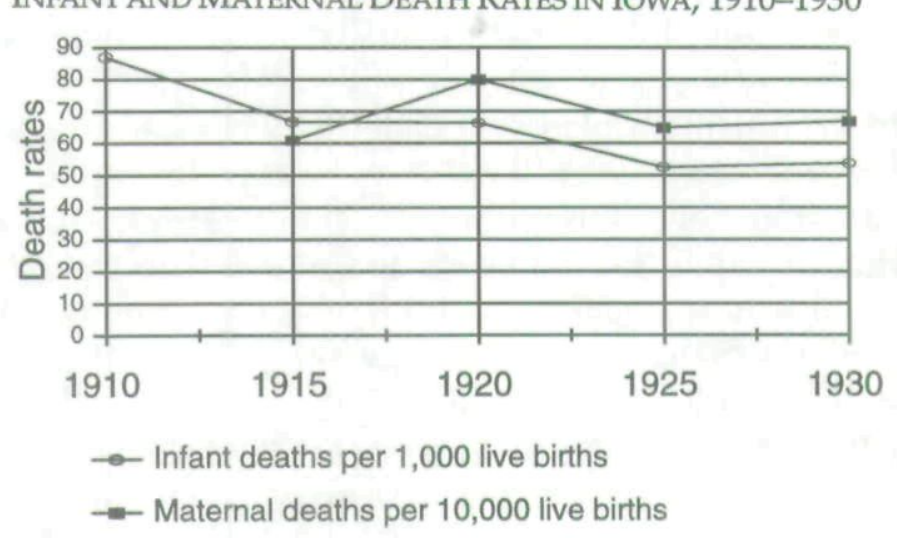

SOURCE: Iowa State Department of Health, Vital Statistics of Iowa, 1975 (Des Moines, 1977), Table 2, "Population, Live Births (Total and Out of Wedlock), Deaths (Total, Infant, Neonatal, Fetal and Maternal), Marriages and Dissolutions, by Year, 1915-1975." The data before 1924 are incomplete.

ports from Iowa over the next decades stressed the complexity of children's cognitive and physical growth and skills, and the influence of health, family, and education on them. ${ }^{123}$

By 1919, Iowa families could turn to infant care pamphlets, baby health contests, fair exhibits, and a few city volunteer clinics for information on how to keep their babies well. But infant mortality in Iowa, while certainly lower than the rates in many urban tenement areas, did not decline as expected (see fig. 2). The rate of deaths of women from childbirth-related causes, including puerperal sepsis, also seemed unaffected by the changes in medical knowledge and practice that had started to send other death rates down. According to national data in 1917, puerperal infection and eclampsia caused more than two-thirds of maternal deaths; both were believed to be preventable if pregnant women sought proper medical care. The rates in the United States, moreover, were significantly higher than those in

123. Hamilton Cravens, Before Head Start: The Iowa Station and America's Children (Chapel Hill, NC, 1993). 
Western European countries, which demonstrated to activists that change was possible. ${ }^{124}$ Clearly, reformers thought, the right information on prenatal health and infant care was not getting through to mothers.

In 1919, using a plan formulated by Julia Lathrop, Senator Morris Sheppard from Texas and Representative Horace Towner from Iowa introduced a bill to Congress that would provide matching federal funds to states to pay for examinations and education for expectant mothers and young children. The act was finally passed late in 1921; the Iowa legislature signed on to it, with the guarantee of matching funds, in April 1923. Even before the legislature agreed (it was not in session in the spring of 1922), Governor Nathan Kendall had placed responsibility for carrying out the purposes of the act in the hands of "a new division of extension . . . added to the University, a division to be known as that of Maternity and Infant Hygiene." Under Dr. O. E. Klingman and an advisory council that included "the professor of nutrition in the child welfare research station," the new division helped to set up diagnostic clinics for pregnant women and children around the state. ${ }^{125}$

Those involved had to keep repeating that the clinics were for diagnosis and education only, not for medical treatment, because physician critics saw the Sheppard-Towner Act as the thin

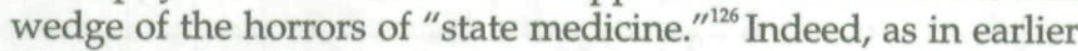
educational work, the physicians who served in the clinics told the mothers in no uncertain terms that they, and their children, must see a family physician regularly and that they should deliver their children in hospitals.

The clinics were much more popular than expected. By December 1923, 10,520 Iowa children under the age of seven had been inspected. "Parents came miles over all kinds of roads when there was no clinic nearer," wrote Dr. Josephine Rust, one

124. Meckel, Save the Babies, 202-5; Kate Harpel [MD, Boone], "The SheppardTowner Bill," JISMS 12 (1922), 265-67.

125. [Untitled editorial], JISMS 12 (1922), 460; "[Sheppard Towner Act]-Public -No. 97-67th Congress-S. 1039," JISMS 12 (1922), 68-70.

126. "Hospital Notes," JISMS 13 (1923), 38; "Meeting of Field Activities Committee and Council of Iowa State Medical Society" JISMS 13 (1923), 65; "An Act to Accept the Provisions and the Benefits ..." JISMS 13 (1923), 256. 
of the division's physicians. She attributed the program's popularity partly to the support of the farm bureaus, which reached families in rural areas. Many children (17 percent) were found to be malnourished or having various "defects." Yet of those told to go to a physician, only "about 30 to 35 percent" had been taken for treatment. ${ }^{127}$

The Iowa Medical Society supported the Sheppard-Towner Act through 1925. During those early years, the society's leadership worked with county medical societies to secure their approval and support for the diagnostic and educational clinics to be held in their townships. By the middle of 1926, however, the tide had turned against federal involvement in state affairs. Medical opinion lashed out particularly against the Children's Bureau, which supervised the act, and its domination by lay people. Editorials in the Journal of the Iowa State Medical Society took to quoting hostile accounts of "the sponsors of the law, largely lay sentimentalists," and were glad that the act would expire at the end of June $1929 .{ }^{128}$ Part of the backlash stemmed from lay criticism of organized medicine's unwillingness to deal with the growing perception that more and more people could not afford medical care and that many rural inhabitants throughout the United States could not find accessible doctors. As much as the Sheppard-Towner clinic work revealed about children's health and maternal ignorance of prenatal care, it revealed even more about the lack of medical care available to rural and even small-town Iowans. Fewer and fewer physicians settled in such areas, and, as Iowa started to suffer from the economic downswing in agriculture in the early 1920s, fewer counties were willing to support county nurses or work on other programs to bring medical services to rural families. ${ }^{129}$ And maternal and infant mortality rates continued as before.

127. Josephine Rust, "Sheppard-Towner Work in Iowa," JISMS 14 (1924), 446-49. 128."The Sheppard-Towner Law," JISMS 17 (1927), 138; "The SheppardTowner Act," JISMS 16 (1926), 381.

129. Rust, "Sheppard-Towner Work in Iowa," 469; "Report of the Committee on Public Policy and Legislation," JISMS 15 (1925), 406-7. 


\section{Conclusion}

The transformation of medical knowledge and practice in Iowa between 1887 and 1928 stemmed from the labors of European and North American scientists and clinicians working, for the most part, in a new culture of research laboratories and large teaching hospitals. Actually getting that knowledge, practice, and laboratory-based culture to Iowa's doctors, public health workers, and citizens, however, required political will, state funding, and physicians' serious personal commitment to keep up with changing theories and therapies. The step-by-step efforts of the Iowa Board of Medical Examiners, while far less exciting than Abraham Flexner's exposé reports on medical schools, illustrate the vital role that state laws had in reshaping medical education. The growing academic quality of the University of Iowa's College of Medicine undoubtedly depended, as well, on legislative willingness to fund its expansion and then to match the unprecedented grant from the Rockefeller Foundation and General Education Board. The work that members of the Iowa Medical Society did to stimulate continuing awareness and discussion of new ideas and treatments at meetings and in their Journal at least partly bridged the gaps between elite, academic, and increasingly specialist physicians and the ordinary, small-town general practitioners who, as the years passed, saw younger doctors with much more formal education entering practice. ${ }^{130}$

Laboratory medicine came to Iowa most obviously with the study of bacteriology and the use of its tools to diagnose and monitor some of the major infectious diseases of humans and animals. The public health response, once devoted to urban sanitation and quarantine of those with clear symptoms of disease, became more complex with the recognition that both people and animals could be healthy-looking carriers of dangerous germs. Scrutiny of disease and death rates, compiled as the modernizing state gathered data on its citizens, revealed disturbingly high maternal and infant mortality rates, along with

130. Markham, "The Passing of the Old Time 'Family Doctor"'; O. C. Morrison, "The Passing of the General Practitioner," JISMS 15 (1925), 26-30. 
growing problems in rural sanitation. ${ }^{131}$ As physicians began to retreat from rural practice and hospitals multiplied, the consequences of scientific medicine started to hit home for Iowans. The downswing in farm prosperity after World War I deepened into an international economic depression in the 1930s, swelling the numbers of those who were unprepared to pay for the diagnostic tests, drugs, operations, and expertise that science brought to health care. The disparity between what physicians could do for their patients and what many patients could afford became a painful burden for both doctors and those who needed them.

131. "Chief of Bureau of Chemistry Discusses Rural Sanitation," IMJ 20 (1913), 144-46; "County Health Officer," JISMS 11 (1921), 20; "Rural Sanitation," Iowa Health Bulletin 6 (1921), 7-12; D. C. Steelsmith, "Report of the State Board of Health," Report of the State Department of Health for the Biennial Period Ending June 30, 1930 (Des Moines, 1930), 6; Dorothy Schwieder, "Iowa: The Middle Land," reprinted from Heartland: Comparative Histories of Midwestern States (1988), in Marvin Bergman, ed., Iowa History Reader (Ames, 1996), 1-18; Don S. Kirschner, City and Country: Rural Responses to Urbanization in the 1920s (Westport, CT, 1970), 18-21. 
Copyright of Annals of Iowa is the property of State of Iowa, by \& through the State Historical Society of Iowa and its content may not be copied or emailed to multiple sites or posted to a listserv without the copyright holder's express written permission. However, users may print, download, or email articles for individual use. 